Article

\title{
The Effects of Green Restaurant Attributes on Customer Satisfaction Using the Structural Topic Model on Online Customer Reviews
}

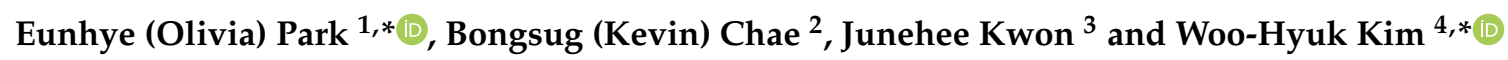 \\ 1 School of Hotel and Tourism Management, The Hong Kong Polytechnic University, Tsim Sha Tsui, \\ Hong Kong, China \\ 2 Department of Management, Kansas State University, Manhattan, KS 66506, USA; bchae@ksu.edu \\ 3 Department of Hospitality Management, Kansas State University, Manhattan, KS 66506, USA; \\ jkwon@ksu.edu \\ 4 Department of Consumer Science, Incheon National University, Incheon 22012, Korea \\ * Correspondence: epark@polyu.edu.hk (E.P.); woohyuk@inu.ac.kr (W.-H.K.)
}

Received: 20 February 2020; Accepted: 1 April 2020; Published: 2 April 2020

\begin{abstract}
Although green practice is increasingly adopted in the restaurant industry, there is still little research in terms of investigating the impacts of green practice on customer satisfaction. This study utilized user-generated content by green restaurant customers to identify various aspects of green restaurants, including perceived green restaurant practices. Our data are based on U.S. green-certified restaurants available on Yelp. Structural topic modeling was used to discover latent restaurant attributes from user-generated content. With a longitudinal approach, the changes in customers' interest in green practices were estimated. Finally, the common restaurant attributes and green attributes were used to predict customer satisfaction. This study will contribute to marketing strategies for the restaurant industry.
\end{abstract}

Keywords: green restaurant; user-generated content; customer satisfaction; topic modeling

\section{Introduction}

The restaurant industry in the United States (U.S.) is comprised of more than one million operations, with 15.3 million employees [1]. Given the close relationships the restaurant industry has with local communities, implementing sustainable (also known as green) restaurant practices has been an important marketing strategy for gaining competitive advantage and organizational legitimacy $[2,3]$. Implementing green practices has become a significant tactic to address public demands related to health and environment concerns, which subsequently leads to the creation of a positive brand image and positive customer attitudes $[4,5]$.

However, incorporating green practices in a restaurant may not always be successful in generating positive emotions among customers. For example, green restaurant practices tend not to be as visible to customers as other marketing efforts [6]. Thus, it is difficult to ascertain whether these attributes are adequately communicated to customers and/or if green attributes create positive outcomes $[4,7]$. In other words, the noticeability of green practices must precede any influence on customer attitudes.

Typically, green practices can inspire positive customer attitudes only when customers recognize a restaurant's efforts to implement them [8]. Recognized green practices may provide auxiliary benefits to customers by fulfilling their emotional needs regarding sustainable concerns and may drive positive customer attitudes [9]. However, the relative impacts of green practices on customer satisfaction may be less significant compared to core restaurant attributes, especially among customers who are indifferent about green practices $[8,10]$. Hence, the relative influence of green practices, compared to 
other restaurant attributes, should also be considered along with the noticeability of green practices in order to evaluate the value of green practices.

Therefore, the purpose of this study is to explore consumer perceptions of green practices using machine learning. A human associative memory theory perspective [11] is considered as a theoretical foundation. This theoretical perspective suggests that customers express their experience of a product or service, which is then positively associated with customer satisfaction. In this vein, the study has four objectives: (1) identify green restaurant practices perceived and expressed in user-generated content (UGC), (2) explore changes in customers' perceptions of green practices, (3) examine the impact of perceived green practices on customer satisfaction ratings, and finally, (4) measure the relative influence of perceived green practices on customer satisfaction ratings, comparing them with restaurant-quality attributes.

In order to capture customers' recognition and the relative impacts of green practices in restaurants on customer satisfaction ratings, this study analyzes a large volume of UGC collected from Yelp.com. Online customer reviews are suitable to investigate whether customers recognize green practices during their restaurant visits and how such recognition influences customer satisfaction ratings.

\section{Literature Review}

\subsection{Structural Topic Modeling (STM)}

Advanced text analytical models or machine learning algorithms (also broadly known as big data analytics techniques) are needed to process and analyze large text corpora [12]. Topic modeling is a statistical modeling method to extract latent topics or themes from large collections of texts, such as online reviews and social media data (e.g., microblogging posts) [13]. Among different topic models explored over the last decade, Latent Dirichlet Allocation (LDA) has become the most popular tool for mining big text data [14]. LDA is a probabilistic topic model assuming that each document contains a mixture of topics with different probabilistic proportions, and that latent topics can be inferred from the distribution of all the words in a text corpus. In LDA, each topic is represented as a distribution of words with different expected proportions [14]. The only information affecting the finding of latent topics is the distribution of words in a corpus. LDA represents an unsupervised statistical machine learning approach to text analysis and thus does not require the input data to be labeled or annotated. This makes the method suitable for big data analysis.

LDA is also known as a generative model (Figure 1), in that the document-topic proportions $(\theta)$ and the probabilistic distribution of words over each topic $(\beta)$ are drawn from a Dirichlet prior distribution. The topic assignment $(z)$ is sampled from $\theta$ per word $(w)$ in each document $(d)$. The result is that each document (or review) is represented as a mixture of $k$ topics in different proportions, and each topic is a mixture of words with different probabilistic contributions $(\beta)$ to the topic. LDA takes a corpus of documents as the input for this generative process.

LDA is developed in Computer Science where the focus is to understand the overall themes from a large corpus. On the other hand, social scientists and behavioral researchers often have additional information about documents or customer reviews. For example, a Yelp review provides meta-data, which include star rating, reviewer type, review date, review length, restaurant type, and location. These covariates are important in hospitality and tourism research when exploring UGC. Structural Topic Modeling (STM) $[15,16]$ is a relatively new probabilistic topic model, incorporating covariates or additional review-level information in the process of inferring topics.

Specifically, STM adds two components to the extent probabilistic topic model, LDA: topic prevalence and topic content. Topic prevalence allows covariates $(X)$ such as the gender and age (e.g., young, old) of reviewers to influence the topic proportion $(\theta)$. For example, if reviews by young people contain topics such as atmosphere and delivery, while reviews by older people focus more on staff service and food quality, researchers can postulate that a covariate (age) affects topic prevalence. 
This means that the topic proportion $(\theta)$ of a document is influenced by covariate $X$, rather than by a Dirichlet prior.

Topic content considers that certain covariates $(Y)$ affect the words representing each topic. For example, some words (e.g., Chow Mein) representing a topic ("food menu") for Chinese restaurants may be different from those (e.g., Pasta Primavera) of Italian restaurants. Thus, the words representing a topic can vary by covariate $Y$.

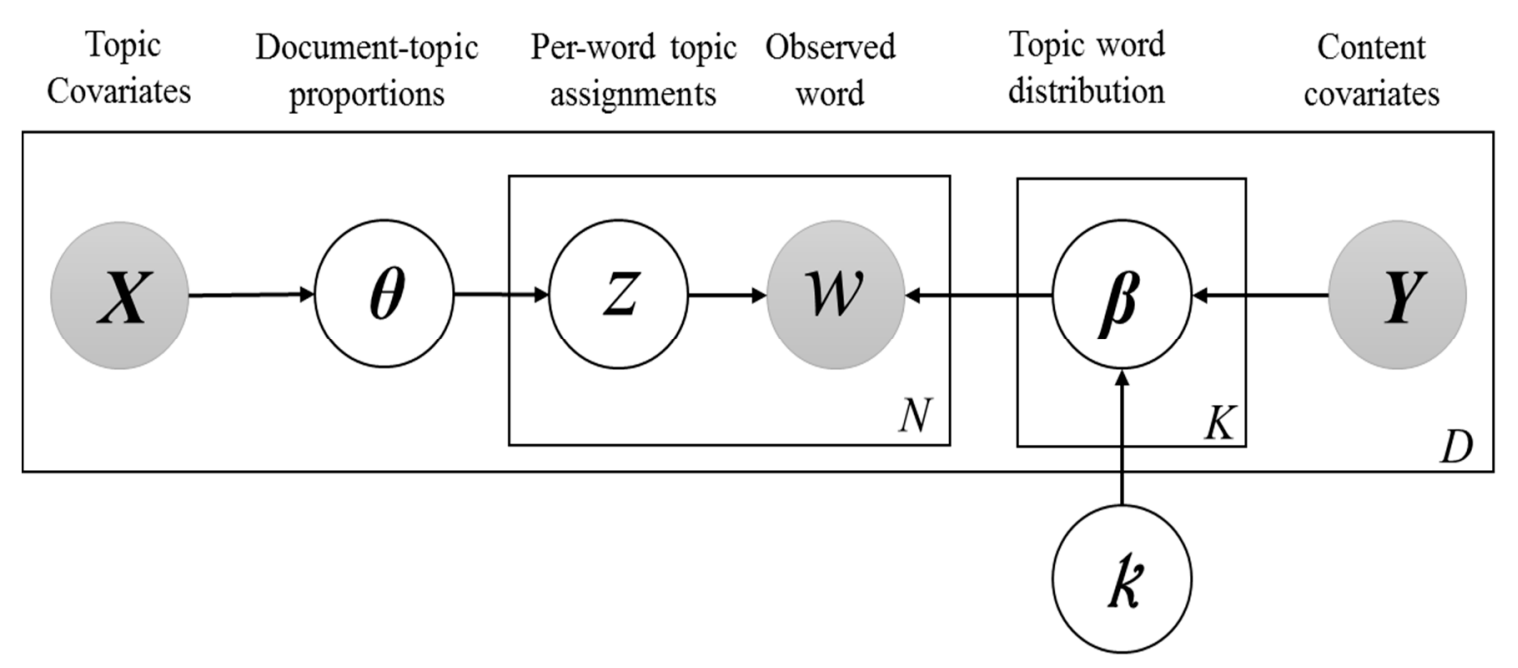

Figure 1. A graphical illustration of Structural Topic Modeling (STM) (Adapted from Roberts et al. [15]).

\subsection{Green Restaurant Attributes and Customer Perceptions}

The range of environmental impacts of the restaurant industry is wide and intensive, from excessive use of water, energy, and resources to high carbon footprints made during the production and delivery of goods, and the transportation of customers and employees [17]. Although there have been attempts to define green attributes, there is a lack of consensus upon which researchers, managers, and customers can agree $[18,19]$.

A green restaurant framework by Choi and Parsa [20] suggested three perspectives in green restaurant practices: health, environmental, and social. Kwok, et al. [21] proposed an alternative framework for green restaurants to include food-, environment-, and administration-focused green practices, based on health and environmental perspectives [20]. The administration-focused practice in this framework measures restaurateurs' efforts to get a green certification or to train employees. Ham and Lee [22] outlined eight categories of green practices (i.e., water efficiency/conservation, waste reduction and recycling, sustainable furnishings, building materials or resources, use of healthy/sustainable food, energy, disposables, chemical and pollution reduction, and organizational green practices) to evaluate restaurants' sustainability practices. Also, Chen, et al. [23] developed the Green Restaurant Service Quality scale (GRSERV scale) by conducting an extensive review of the previous literature on green restaurants and service quality and by performing in-depth interviews with experts in the field.

Grounded in the green restaurant framework, previous studies used predetermined measurements to measure green restaurant customer perceptions [8,21,24]. Following this self-report method, however, it is difficult to examine the noticeability of green practices as green attributes are already present in the measurements. To overcome this issue, this study chose free-recalled texts written by customers who actually visited the green restaurants.

\subsection{Factors Influencing Customer Perception of Green Practices}

Customers who are experiencing the same product or service may pay attention to different aspects of the product/service and respond differently depending on their personal interests [25]. In the 
green restaurant context, it is plausible that customers who experienced "green practices" may have different degrees of interest or recognition for their experiences, depending on their personal values in relation to green practices. Previous studies empirically supported that customers who are conscious about green issues are more likely to perceive green practices as well to have more behavioral intention, such as revisit intention and word-of-mouth (WOM) [4,26,27].

Involvement is defined as the level of psychological link between a stimulus product/purchase and an individual [25]. Customer involvement is dependent upon intrinsic factors, such as the individual customer's traits and values $[28,29]$, and this serves as a major motivator to comprehend certain information and drive explicit behaviors [25,30]. For instance, Cameron [31] proposed the role of involvement in information processing, arguing that involvement in a particular stimulus can increase people's attention to trigger cognitive processing of the corresponding stimulus. Therefore, people with a high level of involvement in the particular attribute are more likely to process the particular stimulus among numerous encountered stimuli [32,33]. The fact that customers have become more knowledgeable and/or conscious of health or environmental issues demonstrates that customers' personal interest in green practices has increased [34-36]. With enhanced customer interest in green practices, such practices may be perceived as more important, and thus, more customers may pay attention to green practices in restaurants.

In addition to customers' personal interest in the products, situational factors play an important role in customer involvement [28]. Accordingly, external/situational factors (e.g., physical environment or product information) are other determinants for the customer comprehension process and behaviors [25,37]. As green practices have become increasingly considered a core activity, many restaurateurs have implemented such practices [22,38]. In turn, it is more likely that customers come to recognize a restaurant's efforts to implement green practices.

Based on the extant literature, this study suggests that customers' involvement can be influenced by situational factors (e.g., green practice implementation) and/or customers' personal interest in green practices. Also, customers with high green practice involvement may be inclined to focus on the related information, which ultimately influences customers' recognition of green practices.

\subsection{Development of Hypotheses}

\subsubsection{Type of Green Practices}

The noticeability of green practices can vary depending on the type of green practices. For example, green practices closely related to core food quality could be more salient for customers as compared to environmentally focused green practices, which may not be as visible [39]. Human Associative Memory (HAM) theory [11] and congruence theory [40] can be useful theoretical foundations to explain customers' higher sensitivity to food-focused green practices as compared to environmentally focused green practices. Customers use their prior expectation and their memory to evaluate new attributes and shape an image [41]. Among numerous attributes, people tend to remember the attributes that are congruent with their expectation and prior memory [42]. Thus, previous studies also emphasized that a good fit between the corporate personality and its socially responsible activities enhances customer perception and attitudes [43-45].

In the restaurant context, the food is a restaurant's key product, and food-related green practices may be more recognizable to customers among various green initiatives through menus and marketing materials [17]. Other environmentally focused practices (e.g., recycling and water saving) mostly happen behind the scenes and may be unnoticed by customers [6]. Based on previous research and the characteristics of green practices, we suggest the following hypotheses:

H1a. Customers visiting green-certified restaurants will recognize food-focused green practices.

H1b. Customers visiting green-certified restaurants will recognize environmentally focused green practices. 
H1c. Customers visiting green-certified restaurants will recognize more food-focused green practices than environmentally focused green practices.

\subsubsection{Relationship between Green Attributes and Customer Attitudes}

The implementation of a restaurant's green practices is expected to generate a competitive advantage by adding extra value to the green firm's products when compared to other restaurants [26,46]. Green practices can provide customers with emotional benefits by satisfying their altruistic or socially conscious inclinations such as the sense of contributing to a cleaner environment [47]. Although customers' personal needs may differ, these green practices may work to fulfill customers' intrinsic needs and ultimately enhance customer satisfaction [8]. In particular, sustainable food can satisfy customers' personal needs such as personal health and trigger positive responses [48-50].

The positive impacts of green practice implementation on customer attitudes are grounded in social identity theory [51], whereby individuals tend to define themselves using social categories, and people choose or support businesses that are congruent with their personal identities. This theory posits that customers who identify themselves as environmentally conscious or health-conscious may be attracted to green restaurants, and this generates positive attitudes toward these businesses [52]. Previous studies have shown that green practices can increase customer satisfaction by satisfying their own personal values for those who value sustainability $[10,53,54]$. Therefore, we hypothesize that:

H2. Perceived green practices will positively influence customer satisfaction ratings.

Moreover, customers tend to evaluate products based on a given set of limited attributes, and the influence of some attributes is more important for customer satisfaction or dissatisfaction than other attributes [55]. However, customers may perceive that the benefits of green practices are less than other common restaurant attributes $[4,10,56]$. This may imply that consumers may be reluctant to give up such core restaurant attributes (e.g., service, food quality) in exchange for environmental benefits [10,57]. Therefore, a comprehensive examination of factors affecting customer satisfaction with consideration of sustainability-related factors may be beneficial for the industry [58,59]. Figure 2 provides shows our conceptual framework. Based on the previous discussion, we hypothesize that:

H3a. Core restaurant-quality attributes will be more prevalent than green attributes.

$\mathbf{H} 3 \mathbf{b}$. The impact of core restaurant-quality attributes on customer satisfaction will be greater than that of green restaurant attributes.
Restaurant attributes that
Restaurant attributes that customers experienced customers expressed in UGC

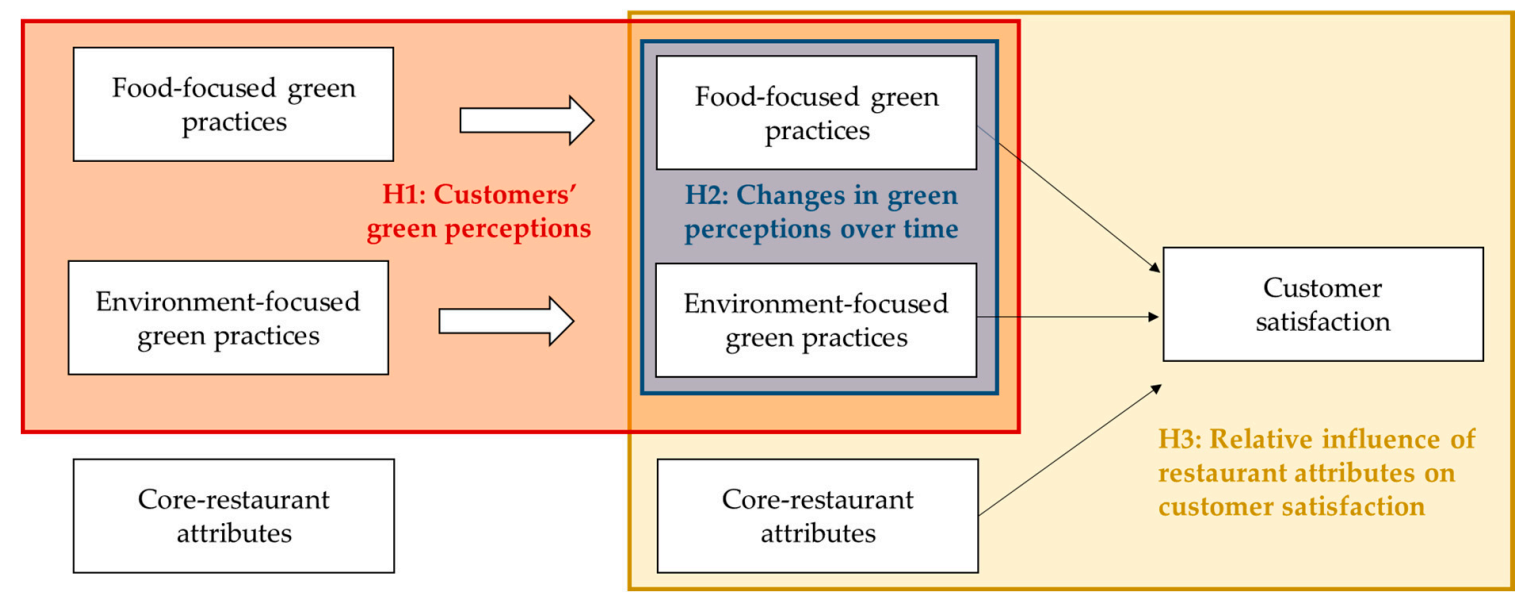

Figure 2. Conceptual framework. 


\section{Materials and Methods}

\subsection{Samples}

To examine customers' perceptions, user-generated content (UGC) written by green restaurant customers was chosen for the further data analysis. UGC was generated based on restaurant attributes that customers experienced and recognized. Thus, UGC represents customers' natural reactions to actual experiences. UGC data were collected from Yelp.com in April 2016. To identify the green restaurants, restaurants officially certified by Green Restaurant Association (GRA) certification were chosen. In the restaurant industry, several green certification programs exist, such as GRA, Green Kitchen certifications, and Green Seal [7]. Among these certification programs, GRA certification was chosen because its standards (i.e., eight environmental categories) are closely related to green attributes proposed by scholars [17,60]. A list of U.S.-based green-certified restaurants was obtained from GRA, and 85,505 online reviews for the 225 restaurants written between 2005 and 2016 were collected using web crawling, an automatic search process to extract relevant data from a website. A web crawler was developed using Selenium in the Python programming language. Selenium (www.seleniumhq.org) is a powerful tool enabling data extraction from dynamic websites such as Yelp. The web crawler visited each of the 225 restaurants' websites on Yelp.com and collected details (e.g., restaurant name, number of reviews) per restaurant. Then, the web crawler navigated and located elements for each review on every restaurant review page. This process can be represented as a list comprehension in Python. For each review, additional review-level information was collected, including review date, restaurant name, and customer satisfaction rating (Table 1).

Table 1. Sample characteristics.

\begin{tabular}{|c|c|c|c|}
\hline Category & Characteristics & $\mathbf{n}$ & $\%$ \\
\hline \multirow{11}{*}{$\begin{array}{l}\text { Customer } \\
\text { review } \\
\text { characteristics }\end{array}$} & \multicolumn{3}{|c|}{ Year of customer review } \\
\hline & Before 2010 & 15,745 & 18.4 \\
\hline & $2011-2012$ & 19,608 & 22.9 \\
\hline & 2013-2014 & 26,935 & 31.5 \\
\hline & 2015-2016 (April) & 23,217 & 27.2 \\
\hline & \multicolumn{3}{|c|}{ Star rating $($ Mean $\pm S D=3.88 \pm 1.16)$} \\
\hline & 1 & 4647 & 5.4 \\
\hline & 2 & 7662 & 9.0 \\
\hline & 3 & 13,010 & 15.2 \\
\hline & 4 & 28,519 & 33.4 \\
\hline & 5 & 31,667 & 37.0 \\
\hline \multirow{14}{*}{$\begin{array}{l}\text { Restaurant } \\
\text { characteristics }\end{array}$} & \multicolumn{3}{|c|}{ Price range } \\
\hline & Less than 10 dollars & 40 & 17.8 \\
\hline & 11-30 dollars & 135 & 60.0 \\
\hline & 31-60 dollars & 39 & 17.3 \\
\hline & Over 60 dollars & 11 & 4.9 \\
\hline & \multicolumn{3}{|c|}{ Aggregated star rating } \\
\hline & $2.5-3.0$ & 29 & 12.9 \\
\hline & $3.5-4.0$ & 164 & 72.9 \\
\hline & $4.5-5.0$ & 32 & 14.2 \\
\hline & \multicolumn{3}{|c|}{ Total number of reviews } \\
\hline & Less than 100 & 76 & 33.8 \\
\hline & $101-200$ & 47 & 20.9 \\
\hline & $201-500$ & 51 & 22.7 \\
\hline & More than 500 & 51 & 22.6 \\
\hline
\end{tabular}

\subsection{Structural Topic Model and Model Validation}

STM was conducted to discover the customers' perceptions from online reviews [16]. Prior to text mining, text preprocessing was applied to the online reviews to clean and transform the text 
corpus for further text mining, following previous study [39]. Like other topic models, including LDA, STM requires researchers to provide the number of topics $(k)$ prior to building a topic model. This stage is called model selection, and there are different methods for model selection in the literature [61]. To determine the best $k$ value, STM suggests two qualities be considered: topic cohesiveness and topic exclusivity [16]. A model is considered cohesive when the top words representing each topic tend to co-appear in a corpus. The model is exclusive when the top words for one topic tend not to appear as top words in other topics. In studies using LDA, the harmonic mean is considered one of the methods to select the best $k$ value $[61,62]$.

In this research, several structural topic models were built with different $k$ values (e.g., 20, 30, $40,50)$, and the diagrams of model cohesiveness and exclusivity were compared. The model appears the best in terms of both qualities when $\mathrm{k}$ is 40 . The study also generated the harmonic mean values using different $\mathrm{k}$ values (2 through 100). The result is almost consistent with that of STM-based model selection. Finally, two domain experts reviewed the results and agreed that 40 is the best $\mathrm{k}$ value.

Manual content analysis was conducted for the online reviews within each topic (1) to label the identified topics and (2) to understand the customer perceptions toward green practices in depth. After researchers identified the preliminary labels for each topic based on the top words, 30 online reviews with the highest loadings for each topic were reviewed to check the appropriateness of the initial labeling. The research team also reviewed 60 online reviews that were classified as green topics to verify online reviews that contained customers' recognition of green practices. Out of 40 topics, 2 topics (topics 13 and 17) were found to be related to green practices.

\subsection{Statistical Analysis}

Descriptive statistics, including frequencies, means, and standard deviations, were calculated to summarize the data using SPSS ver. 22.0 (IBM, Armonk, U.S.). To assess the changes in topic proportions over time, a one-way ANOVA was conducted. To demonstrate the differences in proportions of green reviews over time, a one-way ANOVA and Duncan's post-hoc tests were conducted. After comparing the means of the topic proportion on a yearly basis, we clustered the years into three groups based on a similar number of reviews and post-hoc test results.

To empirically investigate the influence of different attributes on customer satisfaction ratings, multiple regression analysis was conducted with star ratings as the dependent variable and 40 factors as independent variables. Prior to the multiple regression analysis, a recoding process was applied. An STM-based topic model generates the document-topic matrix $(\theta)$, where rows are individual customer reviews and columns are probabilistic proportions for each topic. We recorded the values of the document-topic matrix in the following manner. First, we identified the most prevalent topic in each customer review and kept the probability of the particular topic for the customer review, while recording the other 39 topics as 0 . This recoding process assigned each review to one most salient topic. Topic 40 was excluded from the regression analysis because there were very few reviews on this topic. As a result, the multiple regression analysis included 39 independent variables. Figure 3 provides summary of the methodology. In order to control restaurant-level characteristics, the average food price range and aggregated rating of each restaurant were used as control variables. The absolute values of the standardized coefficient $(\beta)$ were compared to rank the significance of each topic when predicting customer satisfaction ratings (Equation (1)).

Customer satisfaction ratings $=\beta_{0}+\beta_{1}$ Foodprice $+\beta_{2}$ Aggregated restaurant rating $+\beta_{3}$ Topic1 $+\beta_{4}$ Topic $2+\beta_{5}$ Topic3 $+\beta_{39}$ Topic $37+\beta_{40}$ Topic38 $+\beta_{41}$ Topic39 $+\varepsilon$ 


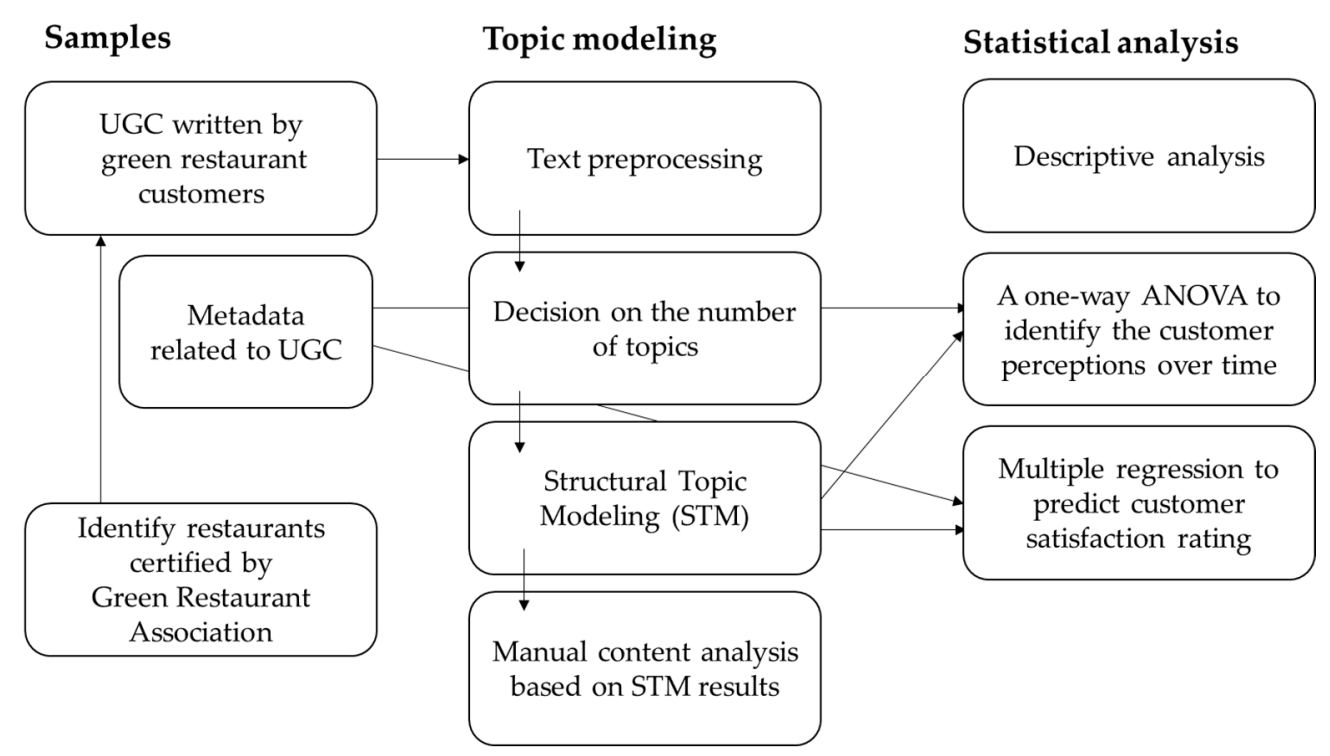

Figure 3. Summary of the methodology.

\section{Results}

\subsection{Topic Modeling}

Since our topic model used 40 as the number of topics, the average proportion per topic is 0.025 (or $2.5 \%$ ). Table A1 provides the forty topics and their top words. Using the document-topic proportion $(\theta)$, we visualized the expected topic proportions of those 40 topics, along with the top three words per topic (Figure 4). Figure 4 shows the overall topic popularity throughout the years (between 2005 and 2016). For example, topic 3 and topic 19, which are largely about great food and location and good food service and staff, respectively, appear to be the two most popular topics in the green restaurant reviews.

\subsection{Customers' Green Perceptions that Appeared in UGC (H1)}

To test hypothesis 1, we used topic modeling. Based on the results of topic modeling, among forty topics, two topics (topics 13 and 17) were identified as food-focused green topics. As shown in Table 2, the highest probability and exclusively appearing high-frequency words provided a basis for naming topics 13 and 17 as "local/organic ingredients" and "vegan menus," respectively. These results supported H1a but failed to support H1b, as only food-focused green practices appeared in UGC. The results showed the occasional appearance of environmentally focused green practices (e.g., "I love how everything here is recycled, some seats are even made from seatbelts!", "Menus printed on heavy stock recycled paper. They are Leadership in Energy and Environmental Design (LEED)-certified, a Certified Green Restaurant, and they also purchase carbon offsets"). However, the number of appearances was not significant enough to form a topic. Therefore, H1c was also supported because food-focused green practices were more prevalent than environmentally focused green practices in UGC. Therefore, H1a and H1c were supported, but H1b was not supported. 


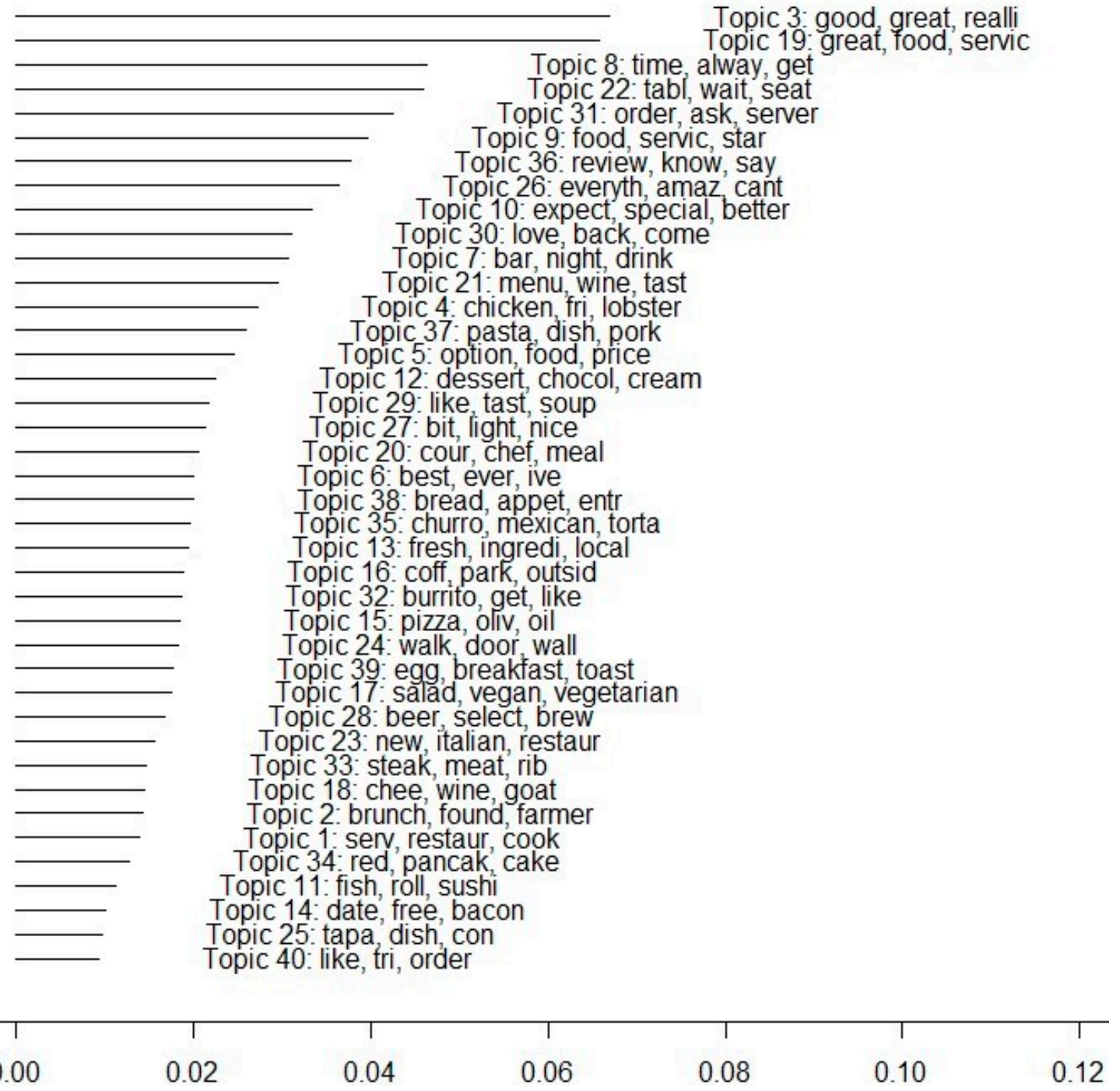

Figure 4. Expected topic proportions.

Table 2. Most frequent words in reviews categorized as two green topics.

\begin{tabular}{cc}
\hline Green Topics & High Frequency Words \\
\hline Local/organic ingredients (T13) & Fresh, ingredi, local, juic, organ, healthy, green, bowl, place, tri \\
\hline Vegan menus (T17) & Salad, vegan, vegetarian, veggi, sandwich, kale, candl, veget, avocado, seitan \\
\hline
\end{tabular}

More specifically, we used the content analysis to demonstrate how customers perceived green practices. For example, one review addressing vegan menu options (ID: 83669) expressed his/her willingness to revisit the place because the green practice satisfied his/her nutritional needs: "( . . ) I also discovered they now have vegan and gluten-free desserts and I had a slice of vegan chocolate cake. It was incredible and my non-vegan friends were in disbelief that it was vegan. I will be visiting there more often now that they can satisfy my nutritional needs and satisfy my insatiable sweet tooth" (written in 2013, 5 stars).

Another reviewer (ID: 86420) expressed positive sentiments toward the green certification and altruistic values associated with green restaurant practices, commenting on local/organic ingredients: "Green-certified food establishment. Say what?! This is awesome. And the food is equally as exciting as the idea of going to an establishment like this. They help support (regional) farmers and buy local when they can. There's a small extra charge for the local grass-fed meat and or cheese but it is worth 
it!" (written in 2016, 5 stars). This reviewer further commented that he/she did not mind paying extra for the green practices.

While some customers were willing to pay high food prices for green practices (ID 86420 in the previous section and ID 63532 in Table 3), the majority of customers expressed their positive experience related to typical restaurant attributes. In other words, even if customers recognized green practices, they tended to give low star rating scores if the typical restaurant attributes were unsatisfactory (ID: 42110, 282) (Table 3).

Table 3. Examples of reviews that mention food-focused green practices.

\begin{tabular}{|c|c|c|}
\hline ID & Year of Customer Review & Content \\
\hline 62704 & 2010 & $\begin{array}{l}\text { "My friend suggested we meet here for lunch, which was } \\
\text { strange, because we usually eat animals when we get together. } \\
\text { After a quick yelp check I texted back, "Vegan, huh?" (...) } \\
\text { Many Yelpers have noted that there's nothing world-changing } \\
\text { about the food, but that the taste is excellent. (The restaurant } \\
\text { name) provided one of the most delicious vegetarian meals I've } \\
\text { had"-Vegan menus (4-star rating) }\end{array}$ \\
\hline 63532 & 2015 & $\begin{array}{l}\text { "They have great juice! I am from the Seattle area and make } \\
\text { fresh green juice } 4 \text { days a week, so I was craving some. I ordered } \\
\text { (menu name). Yes, the price is high, but you are getting a lot of } \\
\text { veggies in that cup! I found out if you buy the cold pressed } \\
\text { already-made from the cooler, it's non-GMO and } \\
\text { organic."-Local/organic ingredients (5-star rating) }\end{array}$ \\
\hline 42110 & 2009 & $\begin{array}{l}\text { "We had vegetarian potstickers as an appetizer which were like } \\
\$ 8 \text { and tiny and really not good. Sad." - Vegan menus (1-star } \\
\text { rating) }\end{array}$ \\
\hline 282 & 2010 & $\begin{array}{l}\text { "Apparently something is healthy if you can put the words } \\
\text { "organic," "Wild," or "Natural" in front of each main ingredient. } \\
\text { (... ) The sliders were small and the ahi was a bit overdone for } \\
\text { my taste"-Local/organic ingredients (2-star rating) }\end{array}$ \\
\hline
\end{tabular}

\subsection{Impacts of Green Perceptions on Customer Attitudes (H2 and H3)}

In order to test hypotheses 2 and 3, we used a multiple regression analysis. In terms of hypothesis 2 , a multiple regression analysis using 39 topics explained $37.7 \%$ of variance in the customer star rating scores $\left(R^{2}=0.377\right)($ Table 4$)$. The local/organic ingredient topic $(b=0.82, \beta=0.03, p<0.001)$ and vegan menu topic $(b=0.70, \beta=0.02, p<0.001)$ were positively correlated to customer star rating scores, supporting hypothesis 2 .

In terms of hypothesis 3 , we investigated the relationship between core restaurant-quality and green restaurant attributes. Based on the results, standardized coefficients of green topics showed that the impacts of "vegan menus" and "local/organic ingredients" on customer satisfaction ratings were 17th and 20th out of 39 topics, respectively. Among the top ten topics with the highest absolute values of standardized coefficients, four were regarding service and three were regarding food taste, which indicated that common restaurant attributes had higher correlations with star rating scores compared to green topics, supporting both H3a and H3b (Table 4). Therefore, hypothesis 3 was supported. 
Table 4. The results of regression analysis.

\begin{tabular}{|c|c|c|c|c|c|}
\hline Rank & Topic Name (Topic Number) & $b$ & $S E$ & $\beta$ & $t$ \\
\hline & (Constant) & 2.116 & 0.038 & & 55.069 \\
\hline & Food price & -0.018 & 0.005 & -0.011 & $-3.415^{* * *}$ \\
\hline & Aggregated restaurant star ratings & 0.486 & 0.010 & 0.148 & $50.432 * * *$ \\
\hline \multicolumn{6}{|c|}{ Topics related to common restaurant attributes } \\
\hline 1 & Bad service encountered (T31) & -5.846 & 0.056 & -0.318 & $-105.101^{* * *}$ \\
\hline 2 & Bad food and slow service (T9) & -5.922 & 0.068 & -0.257 & $-87.305^{* * *}$ \\
\hline 3 & Good food and service (T19) & 2.759 & 0.048 & 0.189 & $57.475^{* * *}$ \\
\hline 4 & Mediocre experience (T10) & -5.658 & 0.102 & -0.157 & $-55.378 * * *$ \\
\hline 5 & Bad taste (steak or meat) (T1) & -7.847 & 0.146 & -0.148 & $-53.722 * * *$ \\
\hline 6 & Clarification of previous reviews (T36) & -3.543 & 0.076 & -0.135 & $-46.890 * * *$ \\
\hline 7 & Long wait (T22) & -2.950 & 0.067 & -0.131 & $-44.157^{* * *}$ \\
\hline 8 & Bad food (T29) & -3.294 & 0.078 & -0.121 & $-42.280 * * *$ \\
\hline 9 & Customer satisfaction about food taste (T26) & 3.401 & 0.113 & 0.085 & $30.000^{* * *}$ \\
\hline 10 & Positive experience (T8) & 2.149 & 0.080 & 0.079 & $26.766^{* * *}$ \\
\hline 17 & Vegan menus (T17) & 0.817 & 0.088 & 0.027 & $9.293 * * *$ \\
\hline 12 & Revisit intention (T30) & 3.516 & 0.175 & 0.055 & $20.130 * * *$ \\
\hline 20 & Local/organic ingredients (T13) & 0.702 & 0.086 & 0.023 & $8.113^{* * *}$ \\
\hline 23 & Overpriced menus (T5) & -0.811 & 0.117 & -0.019 & $-6.906^{* * *}$ \\
\hline 30 & Interior design (T27) & -0.489 & 0.125 & -0.011 & $-3.913 * * *$ \\
\hline 36 & Physical environment (e.g., parking, location) (T16) & 0.211 & 0.094 & 0.006 & 2.238 \\
\hline 37 & Good food (T3) & -0.102 & 0.070 & -0.005 & -1.464 \\
\hline 38 & Restaurant building (T24) & 0.221 & 0.146 & 0.004 & 1.512 \\
\hline \multicolumn{6}{|c|}{ Topics related to restaurant type and menu descriptions } \\
\hline 11 & R/M: Fine dining (T20) & 1.352 & 0.071 & 0.058 & $19.143^{* * *}$ \\
\hline 13 & R/M: Dessert (T12) & 1.138 & 0.088 & 0.037 & $12.971^{* * *}$ \\
\hline 14 & R/M: Burger (T6) & 2.503 & 0.188 & 0.036 & $13.346^{* * *}$ \\
\hline 15 & R/M: Italian (in New York) (T23) & 1.566 & 0.132 & 0.033 & $11.858^{* * *}$ \\
\hline 16 & R/M: Mexican—burrito (T32) & -0.746 & 0.066 & -0.033 & $-11.232^{* * *}$ \\
\hline 18 & R/M: Italian (T38) & 1.412 & 0.146 & 0.027 & $9.644^{* * *}$ \\
\hline 19 & R/M: Mexican (T35) & 0.441 & 0.052 & 0.025 & $8.532 * * *$ \\
\hline 21 & R/M: Beer (T28) & 0.650 & 0.082 & 0.023 & $7.935^{* * *}$ \\
\hline 22 & R/M: Italian (T37) & 0.522 & 0.073 & 0.022 & $7.181^{* * *}$ \\
\hline 24 & $\mathrm{R} / \mathrm{M}$ : Cheese and wine (T18) & 0.966 & 0.145 & 0.018 & $6.668^{* * *}$ \\
\hline 25 & R/M: Steak (T33) & 0.642 & 0.130 & 0.014 & $4.947^{* * *}$ \\
\hline 26 & R/M: Sushi/seafood restaurant (T11) & 0.550 & 0.129 & 0.012 & $4.259^{* * *}$ \\
\hline 27 & R/M: Buffet/brunch (T2) & 0.611 & 0.153 & 0.011 & $4.003^{* * *}$ \\
\hline 28 & R/M: Bar (T7) & 0.509 & 0.127 & 0.011 & $4.007^{* * *}$ \\
\hline 29 & R/M: Gluten-free menu (T14) & 0.616 & 0.155 & 0.011 & $3.983^{* * *}$ \\
\hline 31 & R/M: Fried/grilled foods (T4) & 0.254 & 0.074 & 0.010 & $3.416^{* * *}$ \\
\hline 32 & R/M: Mexican/Latin American (T25) & 0.261 & 0.085 & 0.009 & 3.079 \\
\hline 33 & R/M: Breakfast (T39) & 0.292 & 0.093 & 0.009 & 3.136 \\
\hline 34 & R/M: Dessert (T34) & -0.240 & 0.081 & -0.008 & -2.975 \\
\hline 35 & R/M: Wine (21) & -0.364 & 0.149 & -0.007 & -2.436 \\
\hline 39 & R/M: Pizza (T15) & -0.109 & 0.077 & -0.004 & -1.420 \\
\hline
\end{tabular}

$* * * p<0.001$. Note-R/M: restaurant type or menu description. Rank represents each topic's standardized coefficient value in descending order.

\section{Discussions and Implications}

Although green practice is increasingly adopted in the restaurant industry, there is still little research in terms of investigating the impacts of green practice on customer satisfaction [8]. This study utilized UGC by green restaurant customers, using machine learning to identify various aspects of green restaurants including perceived green practices. We found that customers recognized green practices and shared their perceptions in UGC, but their perceptions were limited to food-related green practices, such as the use of local/organic ingredients and vegan menus. A vegan diet has become a sustainability trend to lessen the harmful ecological impact of meat production due to the heavy use 
of natural resources required for meat production and massive emissions of greenhouse gasses [63]. Also, many environmentally conscious customers prefer to consume local and organic food products, which reduce food miles and the use of chemicals [64]. People are motivated to consume sustainable menus not only due to environmental concerns but also due to health concerns, because they believe sustainable menus have health benefits [20]. The Green Restaurant Association certification standards were developed based on empirical research and include a sustainable food category, which is mainly about the use of locally sourced and naturally grown ingredients and vegan menus [60].

We found that some reviews were related to environment-focused green practices (e.g., recycling programs, sustainable product use). However, the number of these reviews was too low to form a topic. As hypothesized, common restaurant attributes, such as food taste and service quality, were more prevalent in UGC as compared to green attributes. Furthermore, these common restaurant attributes had a stronger influence on customer satisfaction ratings than green attributes. This finding is consistent with a previous study [7].

\subsection{Theoretical Implications}

This study explored unstructured text data from a large volume of online reviews from all over the U.S. based on an assumption that customers would express their perceptions toward restaurant attributes. We also proposed that the level of customer involvement and recognition for those attributes may influence the content that they share in their UGC. Many studies investigated the impact of green practices on behavioral intention (e.g., intention to revisit or leave WOM) using survey methods $[26,65,66]$. Despite the significant contribution of previous studies, social desirability bias is the major concern for self-administered surveys. Thus, this study aims to reduce this issue by analyzing textual data voluntarily provided by a large number of customers who actually visited the green restaurants. Moreover, the structured measurements that are used in a survey presuppose that customers recognize and remember green practices. However, most of the green practices in restaurants are not conspicuous to customers. In online reviews, customers selectively write about attributes that are actually perceived from their experiences. Therefore, analyzing green restaurant UGC, which is generated without researchers' prompts, is advantageous to identify the types of green practices that are more salient to customers and influential on customer attitudes.

Also, we aimed to test the importance of the similarity between core business attributes and the type of green practices in customers' green perceptions. In addition to the visibility of different green practices, this study also proposes that HAM theory and congruency theory may be the theoretical ground for customers' green attribute processing. Also, the findings of this study may imply that customers' involvement in food-focused green practices is greater than environmentally focused green practices. The results were different from previous findings that stated that customers valued environmentally focused green practices more than food-focused green practices $[17,21]$. The different findings may be attributed to the different approaches used to measure customers' green perceptions, as this study used UGC and text mining to uncover customer perceptions.

Furthermore, this study compared the relative influence of green practices to that of common restaurant-quality attributes. While previous studies identified the impacts of green practices in the restaurant setting $[17,21]$, only a few studies included common restaurant practices to identify the relative impacts of green practices [67]. Without considering the competing values (e.g., price, quality of other attributes), the previously suggested effects of green practices may not have the same impact on the actual purchase $[68,69]$. For example, customers who value taste more than green attributes are less likely to be satisfied with a restaurant that serves food with poor taste despite the excellent green attributes provided by the restaurant [10]. However, structured survey questions are often limited in terms of specifically asking about all possible obstacles that keep people from accomplishing a green behavior [68]. Therefore, it is meaningful to uncover natural customer perceptions and reactions to green practices in a manner that lowers potential bias by using post-visit UGC about green restaurants. 


\subsection{Practical Implications}

From a practical perspective, first, understanding the customer sentiments expressed in UGC may help restauranteurs to develop effective marketing strategies, especially for customers who perceive themselves as health-conscious or environmentally conscious [70]. Given the positive association between customers' green perceptions (especially sustainable food green perceptions) expressed in UGC and star rating scores, restauranteurs may focus on highlighting their implementations of providing vegan or organic foods as part of their marketing strategies. For example, restaurants may highlight the list of vegan entrées using a box on a menu board or use visible signs (e.g., a poster board) to show the use of local/organic ingredients in their restaurants [17,71]. Also, the low degree of customer recognition of environmentally focused green practices implies that restauranteurs should promote their engagement in environmentally focused green practices. Environmentally conscious customers tend to identify sustainable firms or find information to make a purchasing decision [35]. Therefore, restauranteurs may promote their engagement in green practices, such as participating in green certification programs, using various media such as online websites or social media.

Second, it is worth noting some negative comments related to sustainable food. Some customers were dissatisfied with the sustainable menu because of its high price and poor taste. Customers' personal needs serve as an important criterion to evaluate their experiences. Naturally, customers who are less interested in sustainability may not appreciate sustainable menus compared to green-conscious customers. However, these negative comments from dissatisfied customers are a good source to improve service quality to satisfy both green-conscious and unconscious customers.

Third, while customers' positive perceptions of green initiatives increase, common restaurant attributes should not be neglected to ensure customer satisfaction. Consistent with previous findings [72], the results show that negative topics had stronger impacts on customer attitudes compared to positive topics. This study found a highly negative influence of bad service on customer satisfaction rating compared to other types of restaurant service failures. Since customers tend to share honest opinions through online reviews, monitoring customer perceptions regarding the performance of specific restaurant attributes can be helpful in order to minimize negative factors and perform better [73].

Finally, the results show a greater negative impact of poor or not-so-special performance on customer satisfaction ratings (topic 10: mediocre experience). When customers dine out, they seek to have memorable experiences beyond relieving hunger [73]. With the increasing number of restaurants, more dining options are available for customers, which drives fierce competition among restaurants. Therefore, restaurants may not be able to retain their customers if they fail to provide exceptional quality [74]. In other words, even though customers did not find anything unsatisfactory in their dining experiences, failure to provide a memorable experience after dining in a certified green restaurant can be perceived negatively, similar to service failures in the competitive restaurant industry.

\section{Limitations and Future Research}

This study has several limitations. First, even though big data analytics is a powerful tool to gain insights from post-visit UGC, this study relied on Yelp.com as a single data source. Therefore, customer sentiments that may have been shared offline or on other online platforms were not included in the dataset. Future research may consider both online reviews from multiple social media platforms and offline customer feedback. Second, since this study explored only green-certified restaurants, which are actively engaged in green practices, the results may not be directly applicable to restaurants with low engagement in sustainable activities. Including non-green restaurants in future research design may improve the ability to compare customers' green perceptions and their impact on attitudes in green-certified and non-green restaurants.

Previous studies found that customers perceive green practices differently depending on the customers' personal characteristics, such as gender, income, and self-perceptions [21,75]. Due to the nature of online UGC, this research could not explore these characteristics. Therefore, it is recommended 
that future research include customers' demographic information and other covariates in topic modeling. Finally, the extant studies have focused on customers' attitudes or behavioral intentions toward green practices and there is limited research incorporating the perspectives of restaurant managers or employees. Therefore, another direction for future research would be evaluating factors such as restaurateur or employee engagement as antecedent variables of customers' green perceptions in restaurant operation.

\section{Conclusions}

In order to identify consumer perceptions of green restaurants expressed in user-generated content, the researchers analyzed restaurant reviews of certified green restaurants using text mining. With the analysis of 85,505 online reviews for 255 certified green restaurants in the U.S., using STM, the salient restaurant attributes perceived by the actual green restaurant customers were identified. Consistent with the global trend, a growing interest in sustainability among customers was also found. While green restaurant customers rarely shared their opinions about environment-focused green practices, they mentioned the food-focused green restaurant practices that they experienced. Moreover, those who mentioned green practices tended to evaluate the restaurant positively. However, such beneficial effects of green practices were not strong enough to counteract their service failure experiences. Our findings imply that practitioners should highlight their green practices without neglecting common restaurant attributes.

Author Contributions: Conceptualization, B.C. and E.P.; methodology, B.C. and E.P.; software, B.C. and E.P.; validation, B.C., E.P. and Z.Z.; formal analysis, B.C. and E.P.; investigation, B.C. and E.P.; resources, B.C. and J.K.; data curation, B.C.; writing - original draft preparation, E.P. and W.-H.K. and J.K.; writing-review and editing, B.C. and W.-H.K.; visualization, E.P.; supervision, W.-H.K. and J.K.; project administration, W.-H.K.; funding acquisition, W.-H.K. All authors have read and agreed to the published version of the manuscript.

Funding: This work was supported by Incheon National University Research Grant in 2019.

Conflicts of Interest: Authors declare no conflict of interest. 


\section{Appendix A}

Table A1. The forty topics and their top words.

\begin{tabular}{|c|c|c|c|c|c|c|c|c|c|c|c|c|c|c|}
\hline Type of Topic & $\begin{array}{r}\mathrm{Nu} \\
\mathrm{Rev}\end{array}$ & $\begin{array}{l}\text { ber of } \\
\text { ws }(\%)\end{array}$ & Topic Label & & & & & & Top Word & & & & & \\
\hline T1. Common QA & 875 & $(1.0 \%)$ & $\begin{array}{c}\text { Bad food (steak or } \\
\text { meat) }\end{array}$ & $\begin{array}{l}\text { PROB } \\
\text { FREX }\end{array}$ & $\begin{array}{c}\text { serv } \\
\text { overcook }\end{array}$ & $\begin{array}{l}\text { restaur } \\
\text { michael }\end{array}$ & $\begin{array}{c}\text { cook } \\
\text { bellagio }\end{array}$ & $\begin{array}{c}\text { cold } \\
\text { undercook }\end{array}$ & $\begin{array}{l}\text { wife } \\
\text { knife }\end{array}$ & $\begin{array}{l}\text { disappoint } \\
\text { temperatur }\end{array}$ & $\begin{array}{c}\text { overcook } \\
\text { jordan }\end{array}$ & $\begin{array}{l}\text { piec } \\
\text { ine }\end{array}$ & $\begin{array}{l}\text { one } \\
\text { tough }\end{array}$ & $\begin{array}{c}\text { plate } \\
\text { microwav }\end{array}$ \\
\hline $\begin{array}{l}\text { T2. Restaurant/menu } \\
\text { description }\end{array}$ & 877 & $(1.0 \%)$ & Buffet/brunch & $\begin{array}{l}\text { PROB } \\
\text { FREX }\end{array}$ & $\begin{array}{l}\text { brunch } \\
\text { buffet }\end{array}$ & $\begin{array}{l}\text { found } \\
\text { farmer }\end{array}$ & $\begin{array}{l}\text { farmer } \\
\text { bloodi }\end{array}$ & $\begin{array}{l}\text { sunday } \\
\text { sunday }\end{array}$ & $\begin{array}{l}\text { locat } \\
\text { found }\end{array}$ & $\begin{array}{l}\text { buffet } \\
\text { fisher }\end{array}$ & $\begin{array}{l}\text { bloodi } \\
\text { brunch }\end{array}$ & $\begin{array}{l}\text { mari } \\
\text { baker }\end{array}$ & $\begin{array}{l}\text { dinner } \\
\text { mimosa }\end{array}$ & $\begin{array}{l}\text { beignet } \\
\text { beignet }\end{array}$ \\
\hline T3. Common QA & 6028 & $(7.0 \%)$ & Good food & $\begin{array}{l}\text { PROB } \\
\text { FREX }\end{array}$ & $\begin{array}{l}\text { good } \\
\text { good }\end{array}$ & $\begin{array}{c}\text { great } \\
\text { nice }\end{array}$ & $\begin{array}{l}\text { realli } \\
\text { pretti }\end{array}$ & $\begin{array}{l}\text { food } \\
\text { realli }\end{array}$ & $\begin{array}{l}\text { nice } \\
\text { great }\end{array}$ & $\begin{array}{c}\text { place } \\
\text { atmosph }\end{array}$ & $\begin{array}{l}\text { pretti } \\
\text { pricey }\end{array}$ & $\begin{array}{l}\text { littl } \\
\text { lunch }\end{array}$ & $\begin{array}{l}\text { lunch } \\
\text { portion }\end{array}$ & $\begin{array}{l}\text { friend } \\
\text { tasti }\end{array}$ \\
\hline $\begin{array}{l}\text { T4. Restaurant/menu } \\
\text { description }\end{array}$ & 3245 & $(3.8 \%)$ & Fried/grilled foods & $\begin{array}{l}\text { PROB } \\
\text { FREX }\end{array}$ & $\begin{array}{l}\text { chicken } \\
\text { chicken }\end{array}$ & $\begin{array}{l}\text { fri } \\
\text { pot }\end{array}$ & $\begin{array}{c}\text { lobster } \\
\text { chowder }\end{array}$ & $\begin{array}{c}\text { green } \\
\text { fri }\end{array}$ & $\begin{array}{c}\text { waffl } \\
\text { cornbread }\end{array}$ & $\begin{array}{c}\text { order } \\
\text { bbq }\end{array}$ & $\begin{array}{l}\text { sauc } \\
\text { lobster }\end{array}$ & $\begin{array}{l}\text { chip } \\
\text { devil }\end{array}$ & $\begin{array}{l}\text { shrimp } \\
\text { soda }\end{array}$ & $\begin{array}{l}\text { tomato } \\
\text { southern }\end{array}$ \\
\hline T5. Common QA & 1408 & $(1.6 \%)$ & Overpriced menus & $\begin{array}{l}\text { PROB } \\
\text { FREX }\end{array}$ & $\begin{array}{l}\text { option } \\
\text { option }\end{array}$ & $\begin{array}{c}\text { food } \\
\text { american }\end{array}$ & $\begin{array}{l}\text { price } \\
\text { fare }\end{array}$ & $\begin{array}{l}\text { place } \\
\text { non }\end{array}$ & $\begin{array}{l}\text { like } \\
\text { chine }\end{array}$ & $\begin{array}{l}\text { lot } \\
\text { sum }\end{array}$ & $\begin{array}{l}\text { qualiti } \\
\text { upscal }\end{array}$ & $\begin{array}{l}\text { mani } \\
\text { hip }\end{array}$ & $\begin{array}{c}\text { restaur } \\
\text { typic }\end{array}$ & $\begin{array}{c}\text { american } \\
\text { term }\end{array}$ \\
\hline $\begin{array}{l}\text { T6. Restaurant/menu } \\
\text { description }\end{array}$ & 674 & $(0.8 \%)$ & Burger & $\begin{array}{l}\text { PROB } \\
\text { FREX }\end{array}$ & $\begin{array}{l}\text { best } \\
\text { burger }\end{array}$ & $\begin{array}{l}\text { ever } \\
\text { ever }\end{array}$ & $\begin{array}{l}\text { ive } \\
\text { best }\end{array}$ & $\begin{array}{c}\text { burger } \\
\text { hamburg }\end{array}$ & $\begin{array}{l}\text { one } \\
\text { eaten }\end{array}$ & $\begin{array}{l}\text { eaten } \\
\text { life }\end{array}$ & $\begin{array}{l}\text { far } \\
\text { ive }\end{array}$ & $\begin{array}{l}\text { life } \\
\text { ring }\end{array}$ & $\begin{array}{c}\text { hand } \\
\text { ketchup }\end{array}$ & $\begin{array}{l}\text { meal } \\
\text { crow }\end{array}$ \\
\hline $\begin{array}{c}\text { T7. Restaurant/menu } \\
\text { description }\end{array}$ & 1462 & $(1.6 \%)$ & Bar & $\begin{array}{l}\text { PROB } \\
\text { FREX }\end{array}$ & $\begin{array}{l}\text { bar } \\
\text { bar }\end{array}$ & $\begin{array}{c}\text { night } \\
\text { bartend }\end{array}$ & $\begin{array}{l}\text { drink } \\
\text { night }\end{array}$ & $\begin{array}{l}\text { hour } \\
\text { late }\end{array}$ & $\begin{array}{l}\text { happi } \\
\text { friday }\end{array}$ & $\begin{array}{l}\text { friend } \\
\text { drink }\end{array}$ & $\begin{array}{l}\text { bartend } \\
\text { fun }\end{array}$ & $\begin{array}{l}\text { fun } \\
\text { monday }\end{array}$ & $\begin{array}{c}\text { sit } \\
\text { happi }\end{array}$ & $\begin{array}{l}\text { dinner } \\
\text { hour }\end{array}$ \\
\hline T8. Customer attitude & 674 & $(0.8 \%)$ & Positive experience & $\begin{array}{l}\text { PROB } \\
\text { FREX }\end{array}$ & $\begin{array}{l}\text { time } \\
\text { alway }\end{array}$ & $\begin{array}{l}\text { alway } \\
\text { usual }\end{array}$ & $\begin{array}{c}\text { get } \\
\text { favorit }\end{array}$ & $\begin{array}{l}\text { make } \\
\text { time }\end{array}$ & $\begin{array}{c}\text { favorit } \\
\text { everi }\end{array}$ & $\begin{array}{l}\text { ive } \\
\text { often }\end{array}$ & $\begin{array}{c}\text { never } \\
\text { sometim }\end{array}$ & $\begin{array}{c}\text { one } \\
\text { never }\end{array}$ & $\begin{array}{l}\text { everi } \\
\text { youll }\end{array}$ & $\begin{array}{l}\text { place } \\
\text { town }\end{array}$ \\
\hline T9. Common QA & 3592 & $(4.1 \%)$ & $\begin{array}{l}\text { Bad food and slow } \\
\text { service }\end{array}$ & $\begin{array}{l}\text { PROB } \\
\text { FREX }\end{array}$ & $\begin{array}{l}\text { food } \\
\text { slow }\end{array}$ & $\begin{array}{l}\text { servic } \\
\text { loud }\end{array}$ & $\begin{array}{c}\text { star } \\
\text { terribl }\end{array}$ & $\begin{array}{l}\text { place } \\
\text { star }\end{array}$ & $\begin{array}{l}\text { give } \\
\text { rate }\end{array}$ & $\begin{array}{l}\text { time } \\
\text { hear }\end{array}$ & $\begin{array}{c}\text { get } \\
\text { annoy }\end{array}$ & $\begin{array}{l}\text { bad } \\
\text { money }\end{array}$ & $\begin{array}{c}\text { dont } \\
\text { horribl }\end{array}$ & $\begin{array}{l}\text { like } \\
\text { noi }\end{array}$ \\
\hline T10. Customer attitude & 1888 & $(2.2 \%)$ & $\begin{array}{l}\text { Mediocre } \\
\text { experience }\end{array}$ & $\begin{array}{l}\text { PROB } \\
\text { FREX }\end{array}$ & $\begin{array}{l}\text { expect } \\
\text { noth }\end{array}$ & $\begin{array}{c}\text { special } \\
\text { okay }\end{array}$ & $\begin{array}{l}\text { better } \\
\text { expect }\end{array}$ & $\begin{array}{c}\text { noth } \\
\text { special }\end{array}$ & $\begin{array}{c}\text { wasnt } \\
\text { averag }\end{array}$ & $\begin{array}{l}\text { price } \\
\text { hype }\end{array}$ & $\begin{array}{l}\text { much } \\
\text { wasnt }\end{array}$ & $\begin{array}{c}\text { disappoint } \\
\text { better }\end{array}$ & $\begin{array}{l}\text { okay } \\
\text { fine }\end{array}$ & $\begin{array}{c}\text { think } \\
\text { wouldn't }\end{array}$ \\
\hline $\begin{array}{l}\text { T11. Restaurant/menu } \\
\text { description }\end{array}$ & 852 & $(1.0 \%)$ & $\begin{array}{c}\text { Sushi/seafood } \\
\text { restaurant }\end{array}$ & $\begin{array}{l}\text { PROB } \\
\text { FREX }\end{array}$ & $\begin{array}{l}\text { fish } \\
\text { sushi }\end{array}$ & $\begin{array}{c}\text { roll } \\
\text { bamboo }\end{array}$ & $\begin{array}{l}\text { sushi } \\
\text { ahi }\end{array}$ & $\begin{array}{l}\text { kid } \\
\text { tuna }\end{array}$ & $\begin{array}{l}\text { seafood } \\
\text { kid }\end{array}$ & $\begin{array}{l}\text { tuna } \\
\text { sustain }\end{array}$ & $\begin{array}{l}\text { sustain } \\
\text { toro }\end{array}$ & $\begin{array}{l}\text { salmon } \\
\text { sashimi }\end{array}$ & $\begin{array}{l}\text { sea } \\
\text { fish }\end{array}$ & $\begin{array}{l}\text { ahi } \\
\text { roll }\end{array}$ \\
\hline $\begin{array}{l}\text { T12. Restaurant/menu } \\
\text { description }\end{array}$ & 1967 & $(2.3 \%)$ & Buffet/Brunch & $\begin{array}{l}\text { PROB } \\
\text { FREX }\end{array}$ & $\begin{array}{c}\text { dessert } \\
\text { tart }\end{array}$ & $\begin{array}{c}\text { chocol } \\
\text { caramel }\end{array}$ & $\begin{array}{l}\text { cream } \\
\text { cream }\end{array}$ & $\begin{array}{c}\text { flavor } \\
\text { vanilla }\end{array}$ & $\begin{array}{c}\text { ice } \\
\text { mouss }\end{array}$ & $\begin{array}{c}\text { sweet } \\
\text { hazelnut }\end{array}$ & $\begin{array}{c}\text { cake } \\
\text { ice }\end{array}$ & $\begin{array}{l}\text { perfect } \\
\text { lemon }\end{array}$ & $\begin{array}{l}\text { rich } \\
\text { mochi }\end{array}$ & $\begin{array}{l}\text { lemon } \\
\text { chocol }\end{array}$ \\
\hline T13. Green QA & 1172 & $(1.4 \%)$ & $\begin{array}{l}\text { Local/healthy } \\
\text { ingredients }\end{array}$ & $\begin{array}{l}\text { PROB } \\
\text { FREX }\end{array}$ & $\begin{array}{l}\text { fresh } \\
\text { juic }\end{array}$ & $\begin{array}{c}\text { ingredi } \\
\text { organ }\end{array}$ & $\begin{array}{c}\text { local } \\
\text { healthi }\end{array}$ & $\begin{array}{l}\text { juic } \\
\text { ingredi }\end{array}$ & $\begin{array}{l}\text { organ } \\
\text { fresh }\end{array}$ & $\begin{array}{l}\text { healthi } \\
\text { smoothi }\end{array}$ & $\begin{array}{c}\text { green } \\
\text { acai }\end{array}$ & $\begin{array}{l}\text { bowl } \\
\text { local }\end{array}$ & $\begin{array}{l}\text { place } \\
\text { ruggl }\end{array}$ & $\begin{array}{l}\text { tri } \\
\text { grown }\end{array}$ \\
\hline $\begin{array}{l}\text { T14. Restaurant/menu } \\
\text { description }\end{array}$ & 704 & $(0.8 \%)$ & Gluten-free menu & $\begin{array}{l}\text { PROB } \\
\text { FREX }\end{array}$ & $\begin{array}{l}\text { date } \\
\text { avec }\end{array}$ & $\begin{array}{l}\text { free } \\
\text { gluten }\end{array}$ & $\begin{array}{c}\text { bacon } \\
\text { date }\end{array}$ & $\begin{array}{c}\text { stuf } \\
\text { shoulder }\end{array}$ & $\begin{array}{l}\text { wrap } \\
\text { free }\end{array}$ & $\begin{array}{l}\text { gluten } \\
\text { allergi }\end{array}$ & $\begin{array}{l}\text { chicago } \\
\text { focaccia }\end{array}$ & $\begin{array}{c}\text { avec } \\
\text { commun }\end{array}$ & $\begin{array}{l}\text { commun } \\
\text { stuf }\end{array}$ & $\begin{array}{l}\text { chorizo } \\
\text { wrap }\end{array}$ \\
\hline $\begin{array}{l}\text { T15. Restaurant/menu } \\
\text { description }\end{array}$ & 2458 & $(2.9 \%)$ & Pizza & $\begin{array}{l}\text { PROB } \\
\text { FREX }\end{array}$ & $\begin{array}{l}\text { pizza } \\
\text { otto }\end{array}$ & $\begin{array}{l}\text { oliv } \\
\text { mozza }\end{array}$ & $\begin{array}{c}\text { oil } \\
\text { pizzeria }\end{array}$ & $\begin{array}{l}\text { mozzarella } \\
\text { mozzarella }\end{array}$ & $\begin{array}{c}\text { mozza } \\
\text { pizza }\end{array}$ & $\begin{array}{c}\text { slice } \\
\text { margherita }\end{array}$ & $\begin{array}{l}\text { crust } \\
\text { osteria }\end{array}$ & $\begin{array}{l}\text { gelato } \\
\text { gelato }\end{array}$ & $\begin{array}{l}\text { pasta } \\
\text { oil }\end{array}$ & $\begin{array}{c}\text { salad } \\
\text { oliv }\end{array}$ \\
\hline T16. Common QA & 1686 & $(2.0 \%)$ & $\begin{array}{c}\text { Physical } \\
\text { environment }\end{array}$ & $\begin{array}{l}\text { PROB } \\
\text { FREX }\end{array}$ & $\begin{array}{c}\text { coff } \\
\text { patio }\end{array}$ & $\begin{array}{l}\text { park } \\
\text { shop }\end{array}$ & $\begin{array}{c}\text { outsid } \\
\text { tea }\end{array}$ & $\begin{array}{c}\text { tea } \\
\text { outdoor }\end{array}$ & $\begin{array}{l}\text { street } \\
\text { park }\end{array}$ & $\begin{array}{l}\text { patio } \\
\text { tree }\end{array}$ & $\begin{array}{c}\text { insid } \\
\text { coff }\end{array}$ & $\begin{array}{l}\text { cafe } \\
\text { coral }\end{array}$ & $\begin{array}{l}\text { area } \\
\text { cup }\end{array}$ & $\begin{array}{c}\text { outdoor } \\
\text { latt }\end{array}$ \\
\hline
\end{tabular}


Table A1. Cont.

\begin{tabular}{|c|c|c|c|c|c|c|c|c|c|c|c|c|c|c|}
\hline Type of Topic & $\begin{array}{r}\mathrm{Nu} \\
\mathrm{Rev}\end{array}$ & $\begin{array}{l}\text { nber of } \\
\text { ews }(\%)\end{array}$ & Topic Label & & & & & & Top Word & & & & & \\
\hline T17. Green QA & 2237 & $(2.6 \%)$ & Vegan menu & $\begin{array}{l}\text { PROB } \\
\text { FREX }\end{array}$ & $\begin{array}{l}\text { salad } \\
\text { seitan }\end{array}$ & $\begin{array}{l}\text { vegan } \\
\text { candl }\end{array}$ & $\begin{array}{l}\text { vegetarian } \\
\text { vegan }\end{array}$ & $\begin{array}{l}\text { veggi } \\
\text { tempeh }\end{array}$ & $\begin{array}{l}\text { sandwich } \\
\text { veggi }\end{array}$ & $\begin{array}{l}\text { kale } \\
\text { kale }\end{array}$ & $\begin{array}{l}\text { candl } \\
\text { quinoa }\end{array}$ & $\begin{array}{c}\text { veget } \\
\text { hummu }\end{array}$ & $\begin{array}{c}\text { avocado } \\
\text { curri }\end{array}$ & $\begin{array}{c}\text { seitan } \\
\text { vegetarian }\end{array}$ \\
\hline $\begin{array}{l}\text { T18. Restaurant/menu } \\
\text { description }\end{array}$ & 866 & $(1.0 \%)$ & Cheese and wine & $\begin{array}{l}\text { PROB } \\
\text { FREX }\end{array}$ & $\begin{array}{l}\text { chee } \\
\text { chee }\end{array}$ & $\begin{array}{l}\text { wine } \\
\text { goat }\end{array}$ & $\begin{array}{c}\text { goat } \\
\text { honey }\end{array}$ & $\begin{array}{l}\text { plate } \\
\text { mac }\end{array}$ & $\begin{array}{c}\text { tomato } \\
\text { flight }\end{array}$ & $\begin{array}{l}\text { grill } \\
\text { pinot }\end{array}$ & $\begin{array}{c}\text { mac } \\
\text { casellula }\end{array}$ & $\begin{array}{l}\text { honey } \\
\text { cheddar }\end{array}$ & $\begin{array}{c}\text { salad } \\
\text { eno }\end{array}$ & $\begin{array}{c}\text { glass } \\
\text { arugula }\end{array}$ \\
\hline T19. Common QA & 8953 & $(10.5 \%)$ & $\begin{array}{l}\text { Good food and } \\
\text { service }\end{array}$ & $\begin{array}{l}\text { PROB } \\
\text { FREX }\end{array}$ & $\begin{array}{l}\text { great } \\
\text { excel }\end{array}$ & $\begin{array}{c}\text { food } \\
\text { fantast }\end{array}$ & $\begin{array}{l}\text { servic } \\
\text { recommend }\end{array}$ & $\begin{array}{l}\text { recommend } \\
\text { outstand }\end{array}$ & $\begin{array}{c}\text { excel } \\
\text { wonder }\end{array}$ & $\begin{array}{c}\text { delici } \\
\text { knowledg }\end{array}$ & $\begin{array}{l}\text { amaz } \\
\text { attent }\end{array}$ & $\begin{array}{l}\text { experi } \\
\text { staff }\end{array}$ & $\begin{array}{l}\text { staff } \\
\text { great }\end{array}$ & $\begin{array}{l}\text { high } \\
\text { servic }\end{array}$ \\
\hline $\begin{array}{l}\text { T20. Restaurant/menu } \\
\text { description }\end{array}$ & 2426 & $(2.8 \%)$ & $\begin{array}{c}\text { Fine dining } \\
\text { restaurant }\end{array}$ & $\begin{array}{l}\text { PROB } \\
\text { FREX }\end{array}$ & $\begin{array}{l}\text { cour } \\
\text { posto }\end{array}$ & $\begin{array}{c}\text { chef } \\
\text { madison }\end{array}$ & $\begin{array}{c}\text { meal } \\
\text { eleven }\end{array}$ & $\begin{array}{l}\text { experi } \\
\text { emp }\end{array}$ & $\begin{array}{l}\text { dine } \\
\text { amus }\end{array}$ & $\begin{array}{c}\text { dish } \\
\text { bouch }\end{array}$ & $\begin{array}{l}\text { tast } \\
\text { del }\end{array}$ & $\begin{array}{c}\text { restaur } \\
\text { cour }\end{array}$ & $\begin{array}{c}\text { duck } \\
\text { michelin }\end{array}$ & $\begin{array}{c}\text { star } \\
\text { blackbird }\end{array}$ \\
\hline $\begin{array}{l}\text { T21. Restaurant/menu } \\
\text { description }\end{array}$ & 1130 & $(1.3 \%)$ & Wine & $\begin{array}{l}\text { PROB } \\
\text { FREX }\end{array}$ & $\begin{array}{l}\text { menu } \\
\text { menu }\end{array}$ & $\begin{array}{l}\text { wine } \\
\text { item }\end{array}$ & $\begin{array}{l}\text { tast } \\
\text { list }\end{array}$ & $\begin{array}{l}\text { item } \\
\text { exten }\end{array}$ & $\begin{array}{c}\text { list } \\
\text { bottl }\end{array}$ & $\begin{array}{l}\text { bottl } \\
\text { wine }\end{array}$ & $\begin{array}{l}\text { restaur } \\
\text { fix }\end{array}$ & $\begin{array}{l}\text { choic } \\
\text { descript }\end{array}$ & $\begin{array}{l}\text { dish } \\
\text { choic }\end{array}$ & $\begin{array}{c}\text { offer } \\
\text { interest }\end{array}$ \\
\hline T22. Common QA & 3940 & $(4.6 \%)$ & $\begin{array}{l}\text { Bad service (long } \\
\text { wait) }\end{array}$ & $\begin{array}{l}\text { PROB } \\
\text { FREX }\end{array}$ & $\begin{array}{c}\text { tabl } \\
\text { hostess }\end{array}$ & $\begin{array}{l}\text { wait } \\
\text { parti }\end{array}$ & $\begin{array}{l}\text { seat } \\
\text { arriv }\end{array}$ & $\begin{array}{l}\text { reserv } \\
\text { minut }\end{array}$ & $\begin{array}{l}\text { minut } \\
\text { reserv }\end{array}$ & $\begin{array}{l}\text { arriv } \\
\text { wait }\end{array}$ & $\begin{array}{c}\text { parti } \\
\text { tabl }\end{array}$ & $\begin{array}{l}\text { get } \\
\text { seat }\end{array}$ & $\begin{array}{l}\text { peopl } \\
\text { readi }\end{array}$ & $\begin{array}{l}\text { hostess } \\
\text { min }\end{array}$ \\
\hline $\begin{array}{l}\text { T23. Restaurant/menu } \\
\text { description }\end{array}$ & 971 & $(1.1 \%)$ & $\begin{array}{c}\text { Italian restaurant in } \\
\text { New York }\end{array}$ & $\begin{array}{l}\text { PROB } \\
\text { FREX }\end{array}$ & $\begin{array}{l}\text { new } \\
\text { west }\end{array}$ & $\begin{array}{c}\text { italian } \\
\text { villag }\end{array}$ & $\begin{array}{c}\text { restaur } \\
\text { york }\end{array}$ & $\begin{array}{l}\text { nyc } \\
\text { nyc }\end{array}$ & $\begin{array}{c}\text { citi } \\
\text { lartusi }\end{array}$ & $\begin{array}{l}\text { york } \\
\text { gem }\end{array}$ & $\begin{array}{c}\text { cozi } \\
\text { charm }\end{array}$ & $\begin{array}{c}\text { small } \\
\text { buvett }\end{array}$ & $\begin{array}{l}\text { wine } \\
\text { pisticci }\end{array}$ & $\begin{array}{l}\text { west } \\
\text { croqu }\end{array}$ \\
\hline T24. Common QA & 1056 & $(1.2 \%)$ & $\begin{array}{c}\text { Restaurant } \\
\text { building }\end{array}$ & $\begin{array}{l}\text { PROB } \\
\text { FREX }\end{array}$ & $\begin{array}{l}\text { walk } \\
\text { wear }\end{array}$ & $\begin{array}{l}\text { door } \\
\text { wall }\end{array}$ & $\begin{array}{c}\text { wall } \\
\text { restroom }\end{array}$ & $\begin{array}{c}\text { like } \\
\text { bathroom }\end{array}$ & $\begin{array}{l}\text { look } \\
\text { men }\end{array}$ & $\begin{array}{l}\text { room } \\
\text { troubl }\end{array}$ & $\begin{array}{l}\text { right } \\
\text { snap }\end{array}$ & $\begin{array}{c}\text { face } \\
\text { air }\end{array}$ & $\begin{array}{c}\text { bathroom } \\
\text { paint }\end{array}$ & $\begin{array}{l}\text { old } \\
\text { fireplac }\end{array}$ \\
\hline $\begin{array}{l}\text { T25. Restaurant/menu } \\
\text { description }\end{array}$ & 1449 & $(1.7 \%)$ & $\begin{array}{l}\text { Mexican/Latin } \\
\text { American }\end{array}$ & $\begin{array}{l}\text { PROB } \\
\text { FREX }\end{array}$ & $\begin{array}{c}\text { tapa } \\
\text { boqueria }\end{array}$ & $\begin{array}{l}\text { dish } \\
\text { mono }\end{array}$ & $\begin{array}{l}\text { con } \\
\text { tapa }\end{array}$ & $\begin{array}{c}\text { sangria } \\
\text { patata }\end{array}$ & $\begin{array}{l}\text { spanish } \\
\text { sangria }\end{array}$ & $\begin{array}{l}\text { ham } \\
\text { croqueta }\end{array}$ & $\begin{array}{l}\text { clam } \\
\text { casa }\end{array}$ & $\begin{array}{c}\text { lamb } \\
\text { spanish }\end{array}$ & $\begin{array}{c}\text { boqueria } \\
\text { tomat }\end{array}$ & $\begin{array}{l}\text { small } \\
\text { paella }\end{array}$ \\
\hline T26. Customer attitude & 2025 & $(2.4 \%)$ & $\begin{array}{c}\text { Customer } \\
\text { satisfaction }\end{array}$ & $\begin{array}{l}\text { PROB } \\
\text { FREX }\end{array}$ & $\begin{array}{l}\text { everyth } \\
\text { everyth }\end{array}$ & $\begin{array}{l}\text { amaz } \\
\text { yum }\end{array}$ & $\begin{array}{c}\text { cant } \\
\text { rememb }\end{array}$ & $\begin{array}{c}\text { delici } \\
\text { cant }\end{array}$ & $\begin{array}{c}\text { got } \\
\text { wow }\end{array}$ & $\begin{array}{c}\text { tri } \\
\text { amaz }\end{array}$ & $\begin{array}{c}\text { eat } \\
\text { boyfriend }\end{array}$ & $\begin{array}{l}\text { thing } \\
\text { glad }\end{array}$ & $\begin{array}{c}\text { order } \\
\text { omg }\end{array}$ & $\begin{array}{c}\text { rememb } \\
\text { knew }\end{array}$ \\
\hline T27. Common QA & 1546 & $(1.8 \%)$ & Interior design & $\begin{array}{l}\text { PROB } \\
\text { FREX }\end{array}$ & $\begin{array}{l}\text { bit } \\
\text { modern }\end{array}$ & $\begin{array}{c}\text { light } \\
\text { interior }\end{array}$ & $\begin{array}{c}\text { nice } \\
\text { bright }\end{array}$ & $\begin{array}{l}\text { decor } \\
\text { decor }\end{array}$ & $\begin{array}{l}\text { dish } \\
\text { light }\end{array}$ & $\begin{array}{l}\text { restaur } \\
\text { beauti }\end{array}$ & $\begin{array}{c}\text { well } \\
\text { design }\end{array}$ & $\begin{array}{l}\text { beauti } \\
\text { present }\end{array}$ & $\begin{array}{c}\text { flavor } \\
\text { ceil }\end{array}$ & $\begin{array}{l}\text { quit } \\
\text { color }\end{array}$ \\
\hline $\begin{array}{l}\text { T28. Restaurant/menu } \\
\text { description }\end{array}$ & 1907 & $(2.2 \%)$ & Beer & $\begin{array}{l}\text { PROB } \\
\text { FREX }\end{array}$ & $\begin{array}{c}\text { beer } \\
\text { breweri }\end{array}$ & $\begin{array}{l}\text { select } \\
\text { kona }\end{array}$ & $\begin{array}{l}\text { brew } \\
\text { beer }\end{array}$ & $\begin{array}{l}\text { tap } \\
\text { pub }\end{array}$ & $\begin{array}{c}\text { craft } \\
\text { ipa }\end{array}$ & $\begin{array}{l}\text { wing } \\
\text { draft }\end{array}$ & $\begin{array}{l}\text { tour } \\
\text { tap }\end{array}$ & $\begin{array}{c}\text { like } \\
\text { brew }\end{array}$ & $\begin{array}{l}\text { ale } \\
\text { rooftop }\end{array}$ & $\begin{array}{l}\text { island } \\
\text { simon }\end{array}$ \\
\hline T29. Common QA & 2337 & $(2.7 \%)$ & Bad food & $\begin{array}{l}\text { PROB } \\
\text { FREX }\end{array}$ & $\begin{array}{l}\text { like } \\
\text { pierogi }\end{array}$ & $\begin{array}{c}\text { tast } \\
\text { veselka }\end{array}$ & $\begin{array}{l}\text { soup } \\
\text { bland }\end{array}$ & $\begin{array}{l}\text { bland } \\
\text { ramen }\end{array}$ & $\begin{array}{c}\text { salti } \\
\text { cabbag }\end{array}$ & $\begin{array}{l}\text { sauc } \\
\text { noodl }\end{array}$ & $\begin{array}{l}\text { potato } \\
\text { borscht }\end{array}$ & $\begin{array}{c}\text { flavor } \\
\text { ukrainian }\end{array}$ & $\begin{array}{l}\text { got } \\
\text { bun }\end{array}$ & $\begin{array}{l}\text { dri } \\
\text { sour }\end{array}$ \\
\hline T30. Customer attitude & 880 & $(1.0 \%)$ & Revisit intention & $\begin{array}{l}\text { PROB } \\
\text { FREX }\end{array}$ & $\begin{array}{l}\text { love } \\
\text { love }\end{array}$ & $\begin{array}{l}\text { back } \\
\text { mom }\end{array}$ & $\begin{array}{l}\text { come } \\
\text { back }\end{array}$ & $\begin{array}{c}\text { place } \\
\text { ago }\end{array}$ & $\begin{array}{l}\text { day } \\
\text { come }\end{array}$ & $\begin{array}{l}\text { husband } \\
\text { soon }\end{array}$ & $\begin{array}{c}\text { first } \\
\text { husband }\end{array}$ & $\begin{array}{c}\text { friend } \\
\text { ill }\end{array}$ & $\begin{array}{l}\text { tri } \\
\text { dad }\end{array}$ & $\begin{array}{l}\text { time } \\
\text { mother }\end{array}$ \\
\hline T31. Common QA & 4612 & $(5.4 \%)$ & $\begin{array}{l}\text { Bad service } \\
\text { encountered }\end{array}$ & $\begin{array}{l}\text { PROB } \\
\text { FREX }\end{array}$ & $\begin{array}{c}\text { order } \\
\text { ask }\end{array}$ & $\begin{array}{l}\text { ask } \\
\text { bill }\end{array}$ & $\begin{array}{c}\text { server } \\
\text { waitress }\end{array}$ & $\begin{array}{l}\text { came } \\
\text { apolog }\end{array}$ & $\begin{array}{c}\text { waiter } \\
\text { brought }\end{array}$ & $\begin{array}{l}\text { took } \\
\text { took }\end{array}$ & $\begin{array}{l}\text { back } \\
\text { told }\end{array}$ & $\begin{array}{c}\text { said } \\
\text { waiter }\end{array}$ & $\begin{array}{c}\text { waitress } \\
\text { manag }\end{array}$ & $\begin{array}{l}\text { time } \\
\text { didn }\end{array}$ \\
\hline $\begin{array}{l}\text { T32. Restaurant/menu } \\
\text { description }\end{array}$ & 1841 & $(2.2 \%)$ & Mexican—burrito & $\begin{array}{l}\text { PROB } \\
\text { FREX }\end{array}$ & $\begin{array}{l}\text { burrito } \\
\text { boloco }\end{array}$ & $\begin{array}{c}\text { get } \\
\text { burrito }\end{array}$ & $\begin{array}{l}\text { like } \\
\text { buck }\end{array}$ & $\begin{array}{l}\text { boloco } \\
\text { boston }\end{array}$ & $\begin{array}{l}\text { cheap } \\
\text { grendel }\end{array}$ & $\begin{array}{l}\text { order } \\
\text { colleg }\end{array}$ & $\begin{array}{l}\text { dont } \\
\text { shake }\end{array}$ & $\begin{array}{l}\text { wrap } \\
\text { buy }\end{array}$ & $\begin{array}{l}\text { buck } \\
\text { cheap }\end{array}$ & $\begin{array}{l}\text { want } \\
\text { cash }\end{array}$ \\
\hline
\end{tabular}


Table A1. Cont.

\begin{tabular}{|c|c|c|c|c|c|c|c|c|c|c|c|c|c|c|}
\hline \multirow{2}{*}{$\begin{array}{c}\text { Type of Topic } \\
\begin{array}{c}\text { T33. Restaurant/menu } \\
\text { description }\end{array}\end{array}$} & \multicolumn{2}{|c|}{$\begin{array}{c}\text { Number of } \\
\text { Reviews (\%) }\end{array}$} & \multirow{2}{*}{$\begin{array}{c}\text { Topic Label } \\
\text { Steak }\end{array}$} & \multicolumn{11}{|c|}{ Top Words } \\
\hline & 1003 & $(1.2 \%)$ & & $\begin{array}{l}\text { PROB } \\
\text { FREX }\end{array}$ & $\begin{array}{l}\text { steak } \\
\text { rib }\end{array}$ & $\begin{array}{l}\text { meat } \\
\text { steak }\end{array}$ & $\begin{array}{l}\text { rib } \\
\text { bone }\end{array}$ & $\begin{array}{c}\text { cook } \\
\text { medium }\end{array}$ & $\begin{array}{l}\text { side } \\
\text { rare }\end{array}$ & $\begin{array}{l}\text { beef } \\
\text { ribey }\end{array}$ & $\begin{array}{c}\text { short } \\
\text { age }\end{array}$ & $\begin{array}{l}\text { rare } \\
\text { prime }\end{array}$ & $\begin{array}{l}\text { potato } \\
\text { filet }\end{array}$ & $\begin{array}{l}\text { tender } \\
\text { short }\end{array}$ \\
\hline $\begin{array}{l}\text { T34. Restaurant/menu } \\
\text { description }\end{array}$ & 1362 & $(1.6 \%)$ & Dessert & $\begin{array}{l}\text { PROB } \\
\text { FREX }\end{array}$ & $\begin{array}{c}\text { red } \\
\text { velvet }\end{array}$ & $\begin{array}{l}\text { pancak } \\
\text { pancak }\end{array}$ & $\begin{array}{c}\text { cake } \\
\text { larchmont }\end{array}$ & $\begin{array}{l}\text { order } \\
\text { red }\end{array}$ & $\begin{array}{l}\text { velvet } \\
\text { crepe }\end{array}$ & $\begin{array}{l}\text { blue } \\
\text { blue }\end{array}$ & $\begin{array}{c}\text { crab } \\
\text { bungalow }\end{array}$ & $\begin{array}{l}\text { salmon } \\
\text { cake }\end{array}$ & $\begin{array}{l}\text { like } \\
\text { crab }\end{array}$ & $\begin{array}{l}\text { sweet } \\
\text { cupcak }\end{array}$ \\
\hline $\begin{array}{l}\text { T35. Restaurant/menu } \\
\text { description }\end{array}$ & 3286 & $(3.8 \%)$ & Mexican & $\begin{array}{l}\text { PROB } \\
\text { FREX }\end{array}$ & $\begin{array}{l}\text { churro } \\
\text { xoco }\end{array}$ & $\begin{array}{c}\text { mexican } \\
\text { bayless }\end{array}$ & $\begin{array}{l}\text { torta } \\
\text { rick }\end{array}$ & $\begin{array}{l}\text { hot } \\
\text { torta }\end{array}$ & $\begin{array}{l}\text { chocol } \\
\text { frontera }\end{array}$ & $\begin{array}{c}\text { line } \\
\text { ahogada }\end{array}$ & $\begin{array}{l}\text { salsa } \\
\text { churro }\end{array}$ & $\begin{array}{c}\text { order } \\
\text { mexican }\end{array}$ & $\begin{array}{l}\text { xoco } \\
\text { mole }\end{array}$ & $\begin{array}{l}\text { sandwich } \\
\text { guacamol }\end{array}$ \\
\hline T36. Others & 2675 & $(3.1 \%)$ & $\begin{array}{c}\text { Clarification of } \\
\text { previous reviews }\end{array}$ & $\begin{array}{l}\text { PROB } \\
\text { FREX }\end{array}$ & $\begin{array}{l}\text { review } \\
\text { review }\end{array}$ & $\begin{array}{c}\text { know } \\
\text { read }\end{array}$ & $\begin{array}{c}\text { say } \\
\text { owner }\end{array}$ & $\begin{array}{l}\text { restaur } \\
\text { yelp }\end{array}$ & $\begin{array}{l}\text { custom } \\
\text { updat }\end{array}$ & $\begin{array}{l}\text { read } \\
\text { custom }\end{array}$ & $\begin{array}{l}\text { one } \\
\text { write }\end{array}$ & $\begin{array}{c}\text { yelp } \\
\text { establish }\end{array}$ & $\begin{array}{l}\text { let } \\
\text { post }\end{array}$ & $\begin{array}{c}\text { see } \\
\text { respon }\end{array}$ \\
\hline $\begin{array}{l}\text { T37. Restaurant/menu } \\
\text { description }\end{array}$ & 3429 & $(4.0 \%)$ & Italian & $\begin{array}{l}\text { PROB } \\
\text { FREX }\end{array}$ & $\begin{array}{l}\text { pasta } \\
\text { babbo }\end{array}$ & $\begin{array}{l}\text { dish } \\
\text { ragu }\end{array}$ & $\begin{array}{l}\text { pork } \\
\text { rind }\end{array}$ & $\begin{array}{l}\text { octopu } \\
\text { octopu }\end{array}$ & $\begin{array}{l}\text { lamb } \\
\text { cheek }\end{array}$ & $\begin{array}{c}\text { tast } \\
\text { gnocchi }\end{array}$ & $\begin{array}{l}\text { ravioli } \\
\text { pasta }\end{array}$ & $\begin{array}{l}\text { grill } \\
\text { liver }\end{array}$ & $\begin{array}{l}\text { babbo } \\
\text { publican }\end{array}$ & $\begin{array}{c}\text { order } \\
\text { tagliatel }\end{array}$ \\
\hline T38. Common QA & 1195 & $(1.4 \%)$ & Good food & $\begin{array}{l}\text { PROB } \\
\text { FREX }\end{array}$ & $\begin{array}{l}\text { bread } \\
\text { sprout }\end{array}$ & $\begin{array}{l}\text { appet } \\
\text { brussel }\end{array}$ & $\begin{array}{c}\text { entr } \\
\text { bread }\end{array}$ & $\begin{array}{l}\text { delici } \\
\text { squash }\end{array}$ & $\begin{array}{c}\text { dessert } \\
\text { pud }\end{array}$ & $\begin{array}{c}\text { start } \\
\text { butternut }\end{array}$ & $\begin{array}{l}\text { share } \\
\text { mussel }\end{array}$ & $\begin{array}{l}\text { corn } \\
\text { risotto }\end{array}$ & $\begin{array}{l}\text { cocktail } \\
\text { corn }\end{array}$ & $\begin{array}{c}\text { roast } \\
\text { entr }\end{array}$ \\
\hline $\begin{array}{l}\text { T39. Restaurant/menu } \\
\text { description }\end{array}$ & 2076 & $(2.4 \%)$ & Breakfast menu & $\begin{array}{l}\text { PROB } \\
\text { FREX }\end{array}$ & $\begin{array}{l}\text { egg } \\
\text { egg }\end{array}$ & $\begin{array}{c}\text { breakfast } \\
\text { hash }\end{array}$ & $\begin{array}{c}\text { toast } \\
\text { breakfast }\end{array}$ & $\begin{array}{l}\text { french } \\
\text { french }\end{array}$ & $\begin{array}{c}\text { bacon } \\
\text { toast }\end{array}$ & $\begin{array}{c}\text { morn } \\
\text { scrambl }\end{array}$ & $\begin{array}{l}\text { hash } \\
\text { morn }\end{array}$ & $\begin{array}{c}\text { sausag } \\
\text { mapl }\end{array}$ & $\begin{array}{l}\text { order } \\
\text { poach }\end{array}$ & $\begin{array}{l}\text { benedict } \\
\text { syrup }\end{array}$ \\
\hline T40. Customer attitude & 3 & $(0.0 \%)$ & Overall satisfaction & $\begin{array}{l}\text { PROB } \\
\text { FREX }\end{array}$ & $\begin{array}{c}\text { like } \\
\text { enough }\end{array}$ & $\begin{array}{l}\text { tri } \\
\text { like }\end{array}$ & $\begin{array}{l}\text { order } \\
\text { enjoy }\end{array}$ & $\begin{array}{l}\text { also } \\
\text { next }\end{array}$ & $\begin{array}{l}\text { one } \\
\text { right }\end{array}$ & $\begin{array}{l}\text { well } \\
\text { way }\end{array}$ & $\begin{array}{l}\text { meal } \\
\text { thing }\end{array}$ & $\begin{array}{l}\text { even } \\
\text { also }\end{array}$ & $\begin{array}{l}\text { get } \\
\text { tri }\end{array}$ & $\begin{array}{l}\text { enjoy } \\
\text { though }\end{array}$ \\
\hline
\end{tabular}




\section{References}

1. State of the Restaurant Industry. Available online: https://www.restaurant.org/research/reports/state-ofrestaurant-industry (accessed on 16 February 2020).

2. Namkung, Y.; Jang, S. Are consumers willing to pay more for green practices at restaurants? J. Hosp. Tour. Res. 2017, 41, 329-356. [CrossRef]

3. Russo, A.; Tencati, A. Formal vs. informal CSR strategies: Evidence from Italian micro, small, medium-sized, and large firms. J. Bus. Ethics 2009, 85, 339-353. [CrossRef]

4. Namkung, Y.; Jang, S.S. Effects of restaurant green practices on brand equity formation: Do green practices really matter? Int. J. Hosp. Manag. 2013, 33, 85-95. [CrossRef]

5. Wang, Y.-F.; Chen, S.-P.; Lee, Y.-C.; Tsai, C.-T.S. Developing green management standards for restaurants: An application of green supply chain management. Int. J. Hosp. Manag. 2013, 34, 263-273. [CrossRef]

6. Kassinis, G.I.; Soteriou, A.C. Greening the service profit chain: The impact of environmental management practices. Prod. Oper. Manag. 2003, 12, 386-403. [CrossRef]

7. DiPietro, R.B.; Cao, Y.; Partlow, C. Green practices in upscale foodservice operations: Customer perceptions and purchase intentions. Int. J. Contemp. Hosp. Manag. 2013, 25, 779-796. [CrossRef]

8. Jeong, E.; Jang, S.S.; Day, J.; Ha, S. The impact of eco-friendly practices on green image and customer attitudes: An investigation in a café setting. Int. J. Hosp. Manag. 2014, 41, 10-20. [CrossRef]

9. Chen, Y.S. The drivers of green brand equity: Green brand image, green satisfaction, and green trust. J. Bus. Ethics 2010, 93, 307-319. [CrossRef]

10. Gao, Y.L.; Mattila, A.S. Improving consumer satisfaction in green hotels: The roles of perceived warmth, perceived competence, and CSR motive. Int. J. Hosp. Manag. 2014, 42, 20-31. [CrossRef]

11. Teichert, T.A.; Schöntag, K. Exploring consumer knowledge structures using associative network analysis. Psychol. Mark. 2010, 27, 369-398. [CrossRef]

12. Wallach, H.M. Topic Modeling: Beyond Bag-of-Words. In Proceedings of the 23rd International Conference on Machine Learning, Pittsburgh, PA, USA, 25-29 June 2006; pp. 977-984.

13. Wang, C.; Blei, D.M. Collaborative Topic Modeling for Recommending Scientific Articles. In Proceedings of the 17th ACM SIGKDD International Conference on Knowledge Discovery and Data Mining, San Diego, CA, USA, 21-24 August 2011; pp. 448-456.

14. Blei, D.M. Probabilistic topic models. Commun. ACM 2012, 55, 77-84. [CrossRef]

15. Roberts, M.E.; Stewart, B.M.; Airoldi, E.M. A model of text for experimentation in the social sciences. J. Am. Stat. Assoc. 2016, 111, 1-49. [CrossRef]

16. Roberts, M.E.; Stewart, B.M.; Tingley, D.; Lucas, C.; Leder-Luis, J.; Gadarian, S.K.; Albertson, B.; Rand, D.G. Structural Topic Models for open-ended survey responses. Am. J. Political Sci. 2014, 58, 1064-1082. [CrossRef]

17. Schubert, F.; Kandampully, J.; Solnet, D.; Kralj, A. Exploring consumer perceptions of green restaurants in the US. Tour. Hosp. Res. 2010, 10, 286-300. [CrossRef]

18. Hopkins, M.S.; Townend, A.; Khayat, Z.; Balagopal, B.; Reeves, M.; Berns, M. The business of sustainability: What it means to managers now. MIT Sloan Manag. Rev. 2009, 51, 20-27.

19. Kim, S.-H.; Lee, K.; Fairhurst, A. The review of "green" research in hospitality, 2000-2014: Current trends and future research directions. Int. J. Contemp. Hosp. Manag. 2017, 29, 226-247. [CrossRef]

20. Choi, G.; Parsa, H. Green practices II: Measuring restaurant managers' psychological attributes and their willingness to charge for the "Green Practices". J. Foodserv. Bus. Res. 2006, 9, 41-63. [CrossRef]

21. Kwok, L.; Huang, Y.K.; Hu, L. Green attributes of restaurants: What really matters to consumers? Int. J. Hosp. Manag. 2016, 55, 107-117. [CrossRef]

22. Ham, S.; Lee, S. US restaurant companies' green marketing via company websites: Impact on financial performance. Tour. Econ. 2011, 17, 1055-1069. [CrossRef]

23. Chen, C.T.; Cheng, C.C.; Hsu, F.S. GRSERV scale: An effective tool for measuring consumer perceptions of service quality in green restaurants. Total Qual. Manag. Bus. Excell. 2015, 26, 355-367. [CrossRef]

24. Slevitch, L.; Mathe, K.; Karpova, E.; Scott-Halsell, S. "Green" attributes and customer satisfaction: Optimization of resource allocation and performance. Int. J. Contemp. Hosp. Manag. 2013, 25, 802-822. [CrossRef]

25. Celsi, R.L.; Olson, J.C. The role of involvement in attention and comprehension processes. J. Consum. Res. 1988, 15, 210-224. [CrossRef] 
26. Han, H.; Hsu, L.-T.J.; Lee, J.-S. Empirical investigation of the roles of attitudes toward green behaviors, overall image, gender, and age in hotel customers' eco-friendly decision-making process. Int. J. Hosp. Manag. 2009, 28, 519-528. [CrossRef]

27. Martinez Garcia de Leaniz, P.; Herrero Crespo, A.; Gómez López, R. Customer responses to environmentally certified hotels: The moderating effect of environmental consciousness on the formation of behavioral intentions. J. Sustain. Tour. 2018, 26, 1160-1177. [CrossRef]

28. Bloch, P.H.; Richins, M.L. A theoretical model for the study of product importance perceptions. J. Mark. 1983, 47,69-81. [CrossRef]

29. Park, D.-H.; Lee, J.; Han, I. The effect of on-line consumer reviews on consumer purchasing intention: The moderating role of involvement. Int. J. Electron. Commer. 2007, 11, 125-148. [CrossRef]

30. Michaelidou, N.; Dibb, S. Product involvement: An application in clothing. J. Consum. Behav. Int. Res. Rev. 2006, 5, 442-453. [CrossRef]

31. Cameron, G.T. Spreading activation and involvement: An experimental test of a cognitive model of involvement. Journal. Q. 1993, 70, 854-867. [CrossRef]

32. Lee, M.; Faber, R.J. Effects of product placement in on-line games on brand memory: A perspective of the limited-capacity model of attention. J. Advert. 2007, 36, 75-90. [CrossRef]

33. Andrews, J.C.; Durvasula, S.; Akhter, S.H. A framework for conceptualizing and measuring the involvement construct in advertising research. J. Advert. 1990, 19, 27-40. [CrossRef]

34. Manaktola, K.; Jauhari, V. Exploring consumer attitude and behaviour towards green practices in the lodging industry in India. Int. J. Contemp. Hosp. Manag. 2007, 19, 364-377. [CrossRef]

35. Huang, H.-C.; Lin, T.-H.; Lai, M.-C.; Lin, T.-L. Environmental consciousness and green customer behavior: An examination of motivation crowding effect. Int. J. Hosp. Manag. 2014, 40, 139-149. [CrossRef]

36. Jang, Y.J.; Kim, W.G.; Lee, H.Y. Coffee shop consumers' emotional attachment and loyalty to green stores: The moderating role of green consciousness. Int. J. Hosp. Manag. 2015, 44, 146-156. [CrossRef]

37. Matthes, J.; Wonneberger, A.; Schmuck, D. Consumers' green involvement and the persuasive effects of emotional versus functional ads. J. Bus. Res. 2014, 67, 1885-1893. [CrossRef]

38. Perramon, J.; del Mar Alonso-Almeida, M.; Llach, J.; Bagur-Femenías, L. Green practices in restaurants: Impact on firm performance. Oper. Manag. Res. 2014, 7, 2-12. [CrossRef]

39. Park, E.; Chae, B.; Kwon, J. Toward understanding the topical structure of hospitality literature: Applying machine learning and traditional statistics. Int. J. Contemp. Hosp. Manag. 2018, 30, 3386-3411. [CrossRef]

40. Zdravkovic, S.; Magnusson, P.; Stanley, S.M. Dimensions of fit between a brand and a social cause and their influence on attitudes. Int. J. Res. Mark. 2010, 27, 151-160. [CrossRef]

41. Anderson, J.R. A spreading activation theory of memory. J. Verbal Learn. Verbal Behav. 1983, 22, $261-295$. [CrossRef]

42. Fiske, S.T.; Pavelchak, M.A. Category-based versus piecemeal-based affective responses: Developments in schema-triggered affect. In Handbook of Motivation and Cognition: Foundations of Social Behavior; Sorrentino, R.M., Higgins, E.T., Eds.; Guilford Press: New York, NY, USA, 1986; pp. 167-203.

43. Bigné-Alcañiz, E.; Currás-Pérez, R.; Ruiz-Mafé, C.; Sanz-Blas, S. Cause-related marketing influence on consumer responses: The moderating effect of cause-brand fit. J. Mark. Commun. 2012, 18, 265-283. [CrossRef]

44. De Jong, M.D.; van der Meer, M. How does it fit? Exploring the congruence between organizations and their corporate social responsibility (CSR) activities. J. Bus. Ethics 2017, 143, 71-83. [CrossRef]

45. Sohn, Y.S.; Han, J.K.; Lee, S.-H. Communication strategies for enhancing perceived fit in the CSR sponsorship context. Int. J. Advert. 2012, 31, 133-146. [CrossRef]

46. Lee, J.S.; Hsu, L.T.; Han, H.; Kim, Y. Understanding how consumers view green hotels: How a hotel's green image can influence behavioural intentions. J. Sustain. Tour. 2010, 18, 901-914. [CrossRef]

47. Hartmann, P.; Apaolaza-Ibáñez, V. Consumer attitude and purchase intention toward green energy brands: The roles of psychological benefits and environmental concern. J. Bus. Res. 2012, 65, 1254-1263. [CrossRef]

48. Stern, P.C.; Dietz, T.; Kalof, L. Value orientations, gender, and environmental concern. Environ. Behav. 1993, 25, 322-348. [CrossRef]

49. Lu, L.; Gursoy, D. Does offering an organic food menu help restaurants excel in competition? An examination of diners' decision-making. Int. J. Hosp. Manag. 2017, 63, 72-81. [CrossRef]

50. Jeong, E.; Jang, S.S. Healthy menu promotions: A match between dining value and temporal distance. Int. J. Hosp. Manag. 2015, 45, 1-13. [CrossRef] 
51. Tajfel, H.; Turner, J. The social identity theory of inter group behavior. In Psychology of Intergroup Relations; Worchel, S., Austin, W.G., Eds.; Nelson: Chicago, IL, USA, 1986.

52. Chan, E.S.; Hawkins, R. Attitude towards EMSs in an international hotel: An exploratory case study. Int. J. Hosp. Manag. 2010, 29, 641-651. [CrossRef]

53. Wang, Q.; Dou, J.; Jia, S. A Meta-Analytic Review of Corporate Social Responsibility and Corporate Financial Performance. Bus. Soc. 2016, 55, 1083-1121. [CrossRef]

54. Gao, Y.L.; Mattila, A.S.; Lee, S. A meta-analysis of behavioral intentions for environment-friendly initiatives in hospitality research. Int. J. Hosp. Manag. 2016, 54, 107-115. [CrossRef]

55. Gwin, C.F.; Gwin, C.R. Product attributes model: A tool for evaluating brand positioning. J. Mark. Theory Pract. 2003, 11, 30-42. [CrossRef]

56. Choi, B.; La, S. The impact of corporate social responsibility (CSR) and customer trust on the restoration of loyalty after service failure and recovery. J. Serv. Mark. 2013, 27, 223-233. [CrossRef]

57. Ginsberg, J.M.; Bloom, P.N. Choosing the right green-marketing strategy. MIT Sloan Manag. Rev. 2004, 46, 79.

58. Carrigan, M.; Attalla, A. The myth of the ethical consumer-Do ethics matter in purchase behaviour? J. Consum. Mark. 2001, 18, 560-578. [CrossRef]

59. Sen, S.; Bhattacharya, C.B. Does doing good always lead to doing better? Consumer reactions to corporate social responsibility. J. Mark. Res. 2001, 38, 225-243. [CrossRef]

60. Green Restaurant Certification Standards. Available online: https://www.dinegreen.com/certificationstandards (accessed on 16 February 2020).

61. Griffiths, T.L.; Steyvers, M. Finding scientific topics. Proc. Natl. Acad. Sci. USA 2004, 101, 5228-5235. [CrossRef]

62. Ponweiser, M. Latent Dirichlet Allocation in R. Ph.D. Thesis, Vienna University of Economics and Business, Vienna, Austria, 2012.

63. Carfi, D.; Donato, A. Coopetitive games for sustainability of global feeding and climate change: Recent developments. J. Environ. Manag. Tour. 2018, 8, 200-205. [CrossRef]

64. Edwards-Jones, G. Does eating local food reduce the environmental impact of food production and enhance consumer health? Proc. Nutr. Soc. 2010, 69, 582-591. [CrossRef]

65. Kim, Y.J.; Njite, D.; Hancer, M. Anticipated emotion in consumers' intentions to select eco-friendly restaurants: Augmenting the theory of planned behavior. Int. J. Hosp. Manag. 2013, 34, 255-262. [CrossRef]

66. Kim, M.-J.; Lee, C.-K.; Gon Kim, W.; Kim, J.-M. Relationships between lifestyle of health and sustainability and healthy food choices for seniors. Int. J. Contemp. Hosp. Manag. 2013, 25, 558-576. [CrossRef]

67. DiPietro, R.B.; Gregory, S.; Jackson, A. Going green in quick-service restaurants: Customer perceptions and intentions. Int. J. Hosp. Tour. Adm. 2013, 14, 139-156. [CrossRef]

68. Vezich, I.S.; Gunter, B.C.; Lieberman, M.D. The mere green effect: An fMRI study of pro-environmental advertisements. Soc. Neurosci. 2017, 12, 400-408. [CrossRef] [PubMed]

69. Vermeir, I.; Verbeke, W. Sustainable food consumption: Exploring the consumer "attitude-behavioral intention" gap. J. Agric. Environ. Ethics 2006, 19, 169-194. [CrossRef]

70. Rim, H.; Yang, S.-U.; Lee, J. Strategic partnerships with nonprofits in corporate social responsibility (CSR): The mediating role of perceived altruism and organizational identification. J. Bus. Res. 2016, 69, 3213-3219. [CrossRef]

71. Ozdemir, B.; Caliskan, O. Menu design: A review of literature. J. Foodserv. Bus. Res. 2015, 18, 189-206. [CrossRef]

72. Han, H.J.; Mankad, S.; Gavirneni, N.; Verma, R. What guests really think of your hotel: Text analytics of online customer reviews. Cornell Hosp. Rep. 2016, 16, 3-17.

73. Pantelidis, I.S. Electronic meal experience: A content analysis of online restaurant comments. Cornell Hosp. Q. 2010, 51, 483-491. [CrossRef]

74. Yan, X.; Wang, J.; Chau, M. Customer revisit intention to restaurants: Evidence from online reviews. Inf. Syst. Front. 2015, 17, 645-657. [CrossRef]

75. Hu, H.H.; Parsa, H.; Self, J. The dynamics of green restaurant patronage. Cornell Hosp. Q. 2010, 51, $344-362$. [CrossRef]

(C) 2020 by the authors. Licensee MDPI, Basel, Switzerland. This article is an open access article distributed under the terms and conditions of the Creative Commons Attribution (CC BY) license (http://creativecommons.org/licenses/by/4.0/). 